\title{
دور العلاقات العامة في مواجهة قضايا المجتمع المحلي (دراسة تطبيقية على عينة من شركات مياه الشرب مواتهات والصرف الصحي)
}

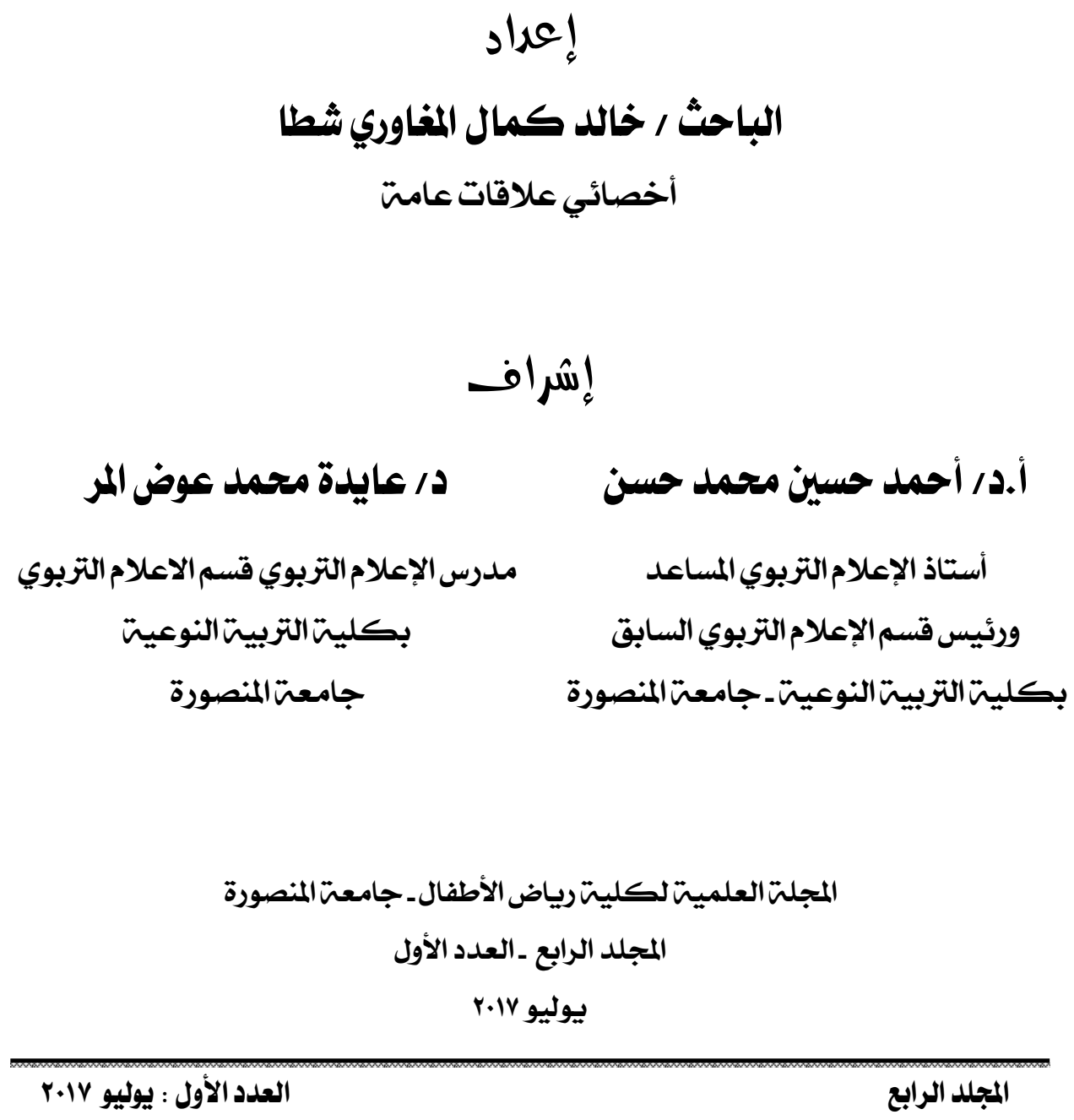


دور العلاقات العامة في مواجهة قضايا المجتمع المحلي (دراسة تطبيقية على عينة من شركات مياه

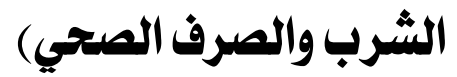

الباحث / خالد كمال المغاوري شطا

تقوم العلاقات العامة بالمنظمات المصرية بدور فعال في تدعيم المصالح

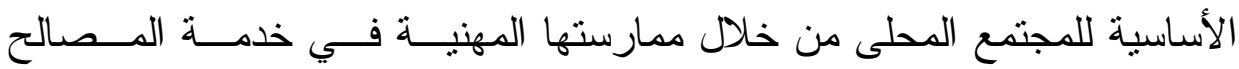
المشتركة بين المنظمات المعاصرة وجماهيرها، ومن خلال الممارســـة العمليــة وجدت أهمية الدور الذي تقدمة إدارة العلاقات العامة في الـشركات المــصرية وخاصة الثركات الخدمية منها ، فلقد إختلف دور العلاقات العامة و أهميتة فـي إني الثركات الخدمية عنه في المنظمات الأخري بسبب نشاط تلك الثركات و أهميتة بالنسبة للمجتمع.

فشركات المياه تقوم بدور خدمي فعال، فهي تمس حياة وأمسـن وصــحة

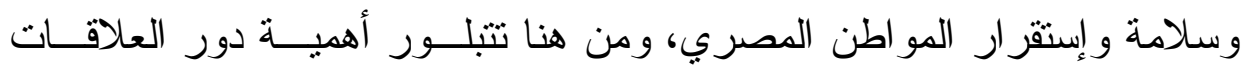
العامة في شركات مياه الثرب و الصرف الصحي، حيث تعمل العلاقات العامـــة

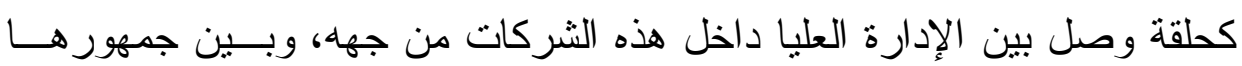
الداخلي و الخارجي من جهه أخري.

" باحث ماجستير * 
لقد جاء الثشعور و الاحساس بالمشكلة البحثية من خلال كـــي مـــواطن

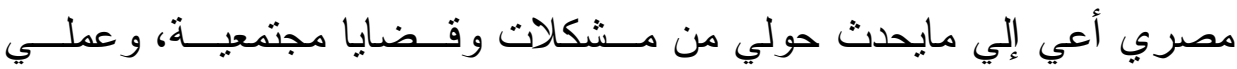

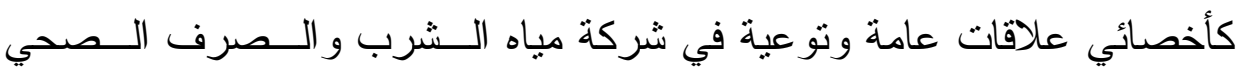
بالدقهلية، وأيضاً باحث في مجال العلاقات العامة، فلاحظت أهمية دور العلاقات فئر الهاه

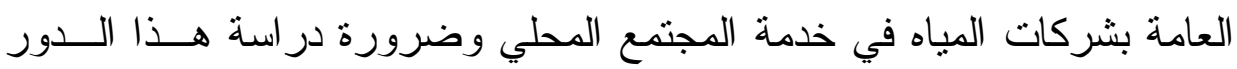

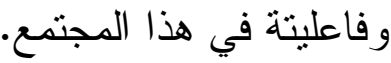

ويناء على ذلك، يمكن صياغة مشكلة البحث كما يلي:

ما دور العلاقات العامة بشركات مياه الثرب والصرف الصحي في مو اجهة قضايا المجتمع المحلي كما ير اها ممارسي العلاقات العامة و الجمهور

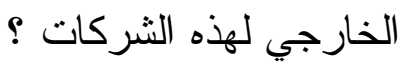

ويتفرع من هذا التساؤل التساؤلات الفرعية التالية:

1- ما أهم أدو ار العلاقات العامة بشركات مياه الثرب و الصرف الصحي تجاه

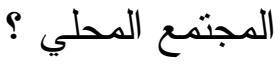

r- ما أبرز قضايا المجتمع المحلي التي تشارك شركات مياه الثرب و الصرف

$$
\text { الصحي في مو اجهتها؟ }
$$

r- هل دور العلاقات العامة في مواجهة قضايا المتمع المحلي ملموس لهذا

المتمع أم لا ؟ المات 


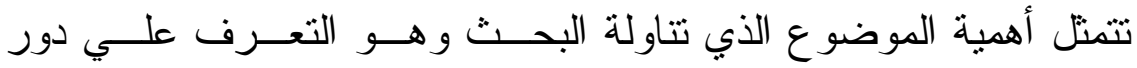

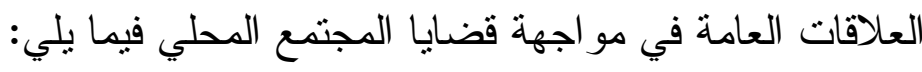
ا. إلقاء الضوء علي دور العلاقات العامة بشركات مياه الثرب و الــصرف الصحي في مو اجهة قضايا المجتمع المحلي. r. يمكن الاستفادة من نتائج هذا البحث في توجيه نظر المسئولين ومتخـــي

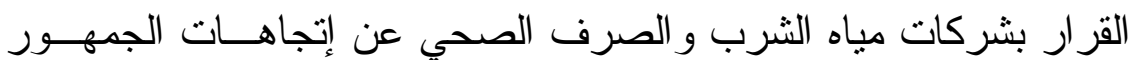

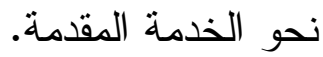
r. يمكن الإفادة من نتائج البحث في خدمة الباحثين في مجال الإعلام حيـث

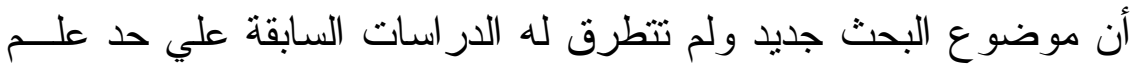
الباحث.

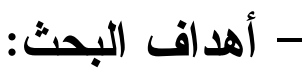
يهدف هذا البحث إلي التعرف علـى دور العلاقـات العامسـة بـشركات

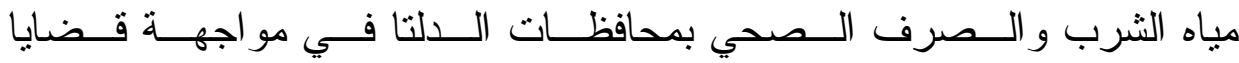

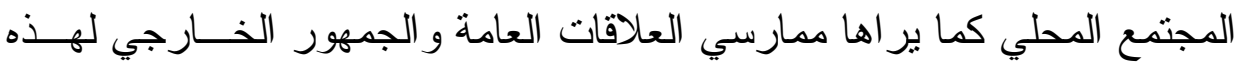

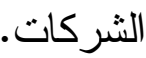

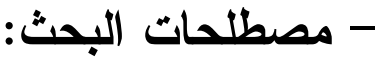

1- العلاقات العامة: ويقصد بهـــا إدارة العلاقـــات العامــة بـشركات ميـــاه

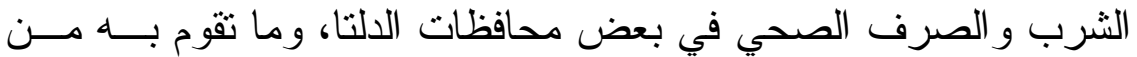

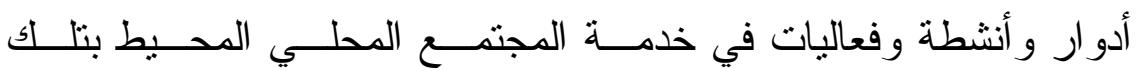

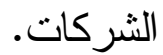


Y- المجتمع المحلي: ويقصد به جمهور المجتمع المحلي المحـبط بـشركات

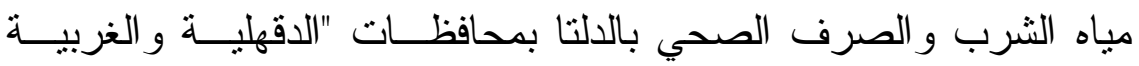
و الثرقية ودمياط وكفر الثيخ".

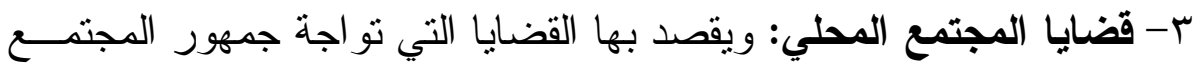

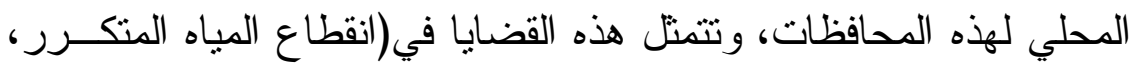

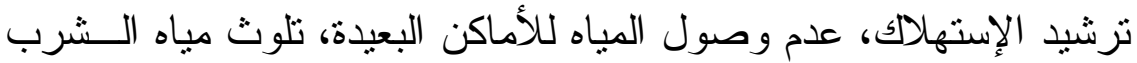

و اختلاطها بالصرف الصحي، الزيادة السكانية، البقع الزيتيـــة فـــي ميــاه

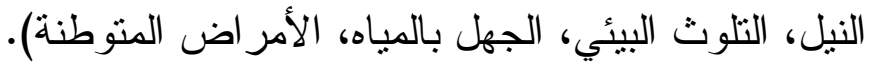

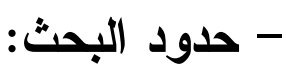

1- الحدود الموضوعية: يقتصر البحث علي الدور الذي تمارســهـ العلاقــات

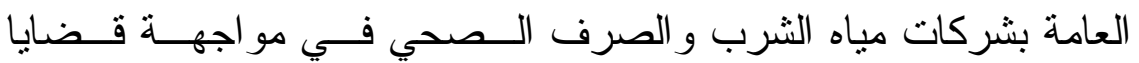

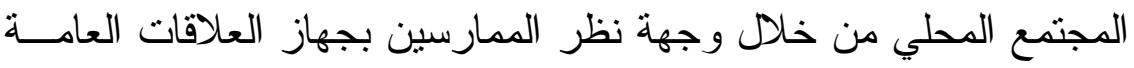

$$
\text { و آر اء الجمهور الخارجي نحو هذه الخدمة. }
$$

r- الحدود المكانية: يقتصر البحث علي ممارسي العلاقات العامة بـشركات

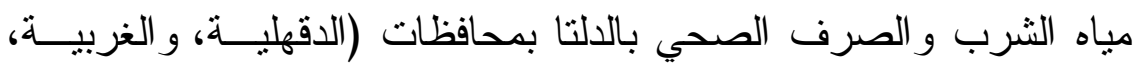

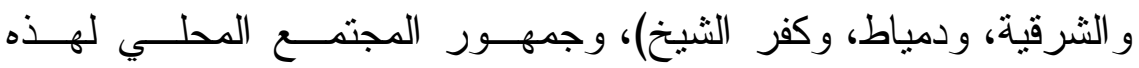

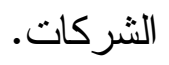

r- الحدود الزمانية: إستغرق تطبيق الإستمارة فترة ستة أثنهر مسن اس-V-

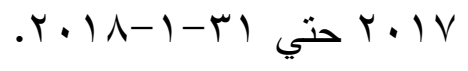

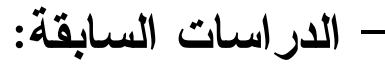

بعد الإطلاع على التزاث العلمي المتاح عن الدراسات العلميــة الــسابقة

المرتبطة بموضو ع البحث، يمكن عرض نلإلك الدر اسات فيما يلي: 


$$
\text { 1 - دراسة هولي ريفز (7 } 1 \text { (ب): }
$$

هدفت الدراسة إلي التعرف علي بر امج المسئولية الاجتماعية للـشركات الأمريكية وكيفية تتفيذها، ومدي تحكم العلاقات العامة في هذه البر امج، و استخدم

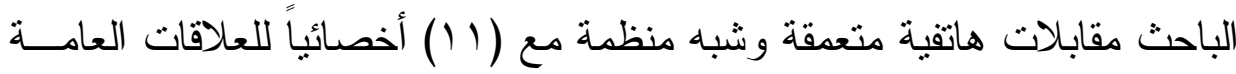

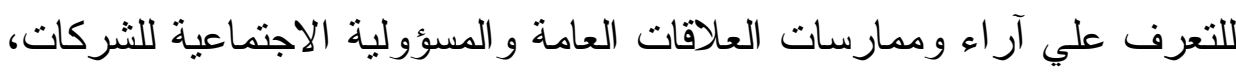
وتوصلت الدراسة الي أن برامج المسئولية الاجتماعية للشركات مستقلة و لاقــات

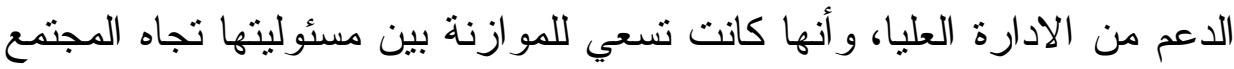

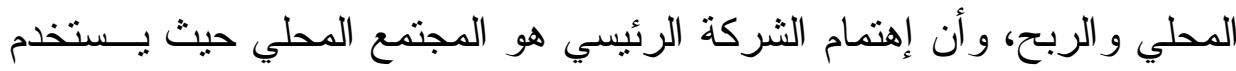

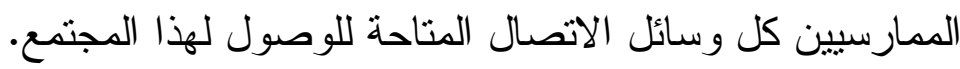

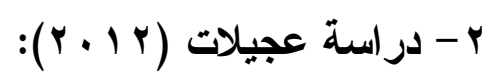

هدفت الدراسة إلي تحديد مفهوم المسئولية الاجتماعية للشركات الخاصة

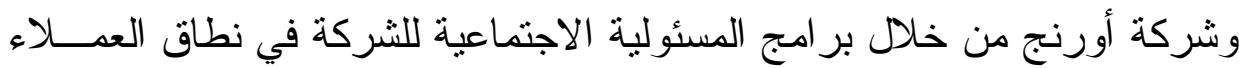

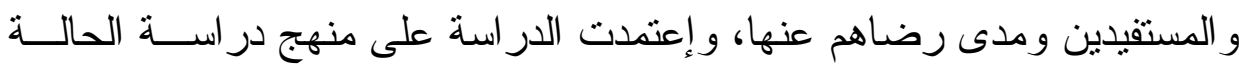

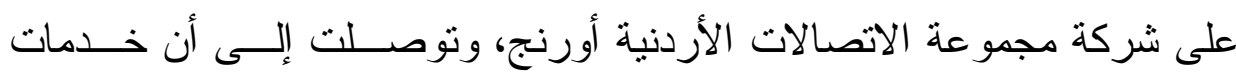

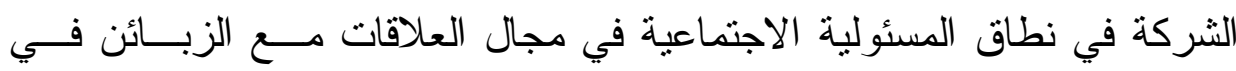

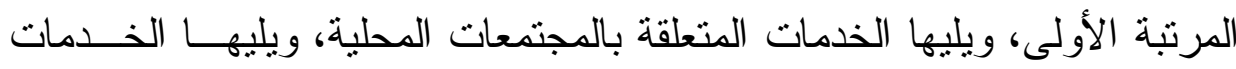

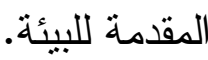

$$
\text { r- دراسة فيرونيكا أيوانا إلياس (11 + r): }
$$

هدفت الدراسة الي التعرف علي مدي الإرتباط بين المسئولية الاجتماعية

للثركات و الجمهور ، و آر اء ممارسي العلاقات العامة حول المسئولية الاجتماعية

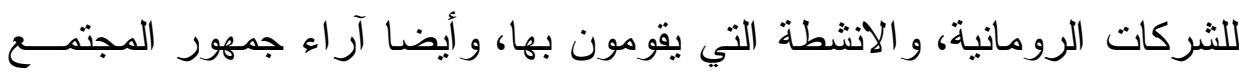

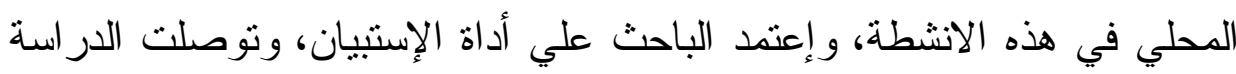


الي عدم وجود فروق في إستجابات عينة الدر اسة من الـــكور و الاتــاث حـول

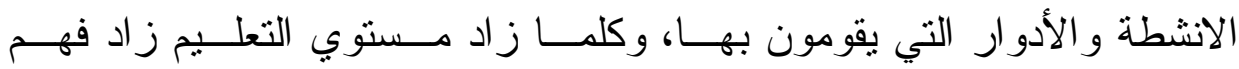

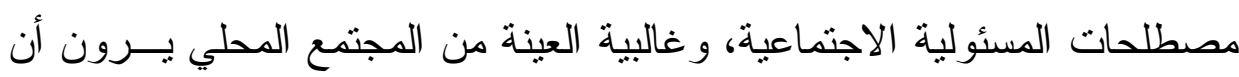

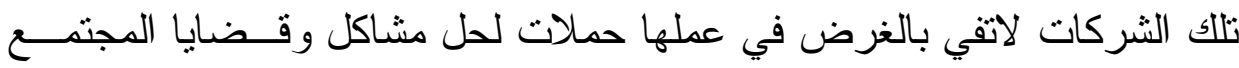
المحلي.

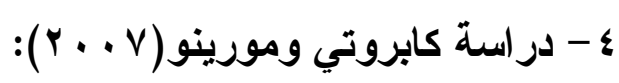

هدفت الدر اسة إلي التعرف على الأدوات التي تستخدمها العلاقات العامــة

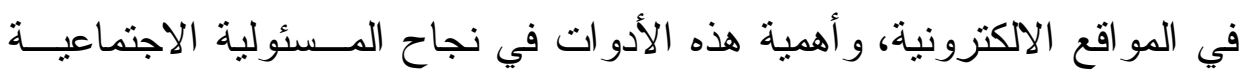

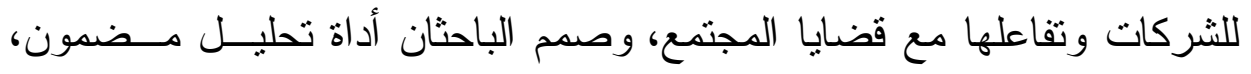

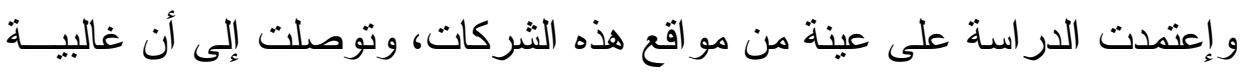

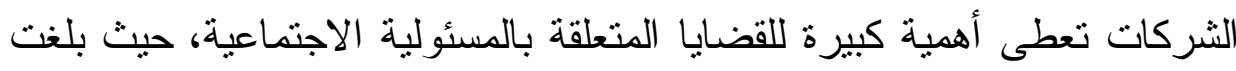

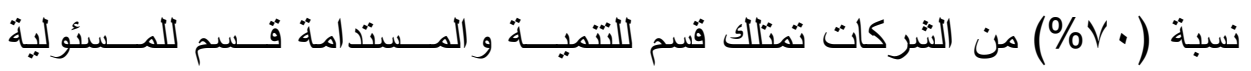

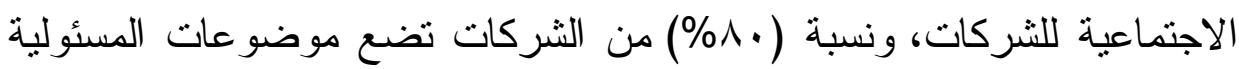
الاجتماعية على الصفحة الرئيسية لموقعها الالكتروني.

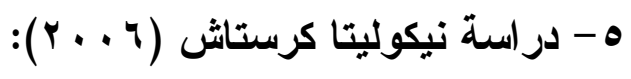

هدفت الدراسة إلي التعرف على المسئولية الاجتماعية للعلاقات العامة في

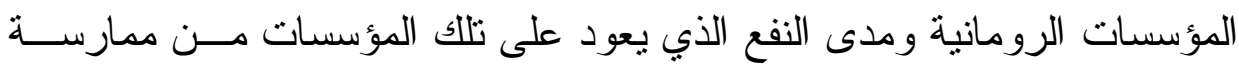

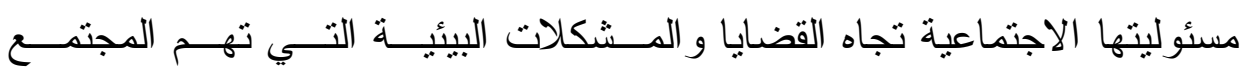
الروماني، وقد إعتمدت الدر اسة على عينة من شـــركات ومؤســسات رومانيـــة

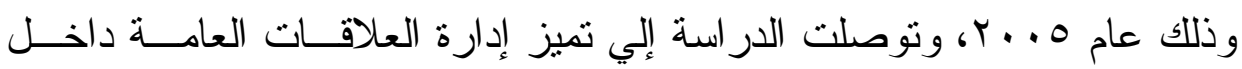

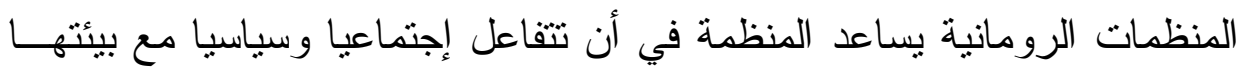

المجلد الرابع


المحيطة، وإبراز دور العلاقات العامة في إنجاح العلاقات مع الجمهــور الــــي يؤدى إلى رفع نسبة أرباح المنظمة وقلة التكاليف.

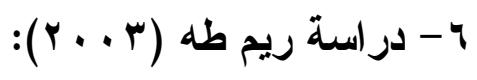

هدفت الدراسة إلى التعرف على الجوانب التتظيميــة لجهــاز العلاقــات العامة داخل تلك المنظمات، وعلى المضامين الإعلامية التي يسـتخدمها جهــاز العلاقات العامة في شركات القطاعين العام و الخاص بالقاهرة الكبرى، إعتــــت الدراسة علي المنهج الوصفي طريقة المسح بالعينة علي عينة عديـــة قوامهــا

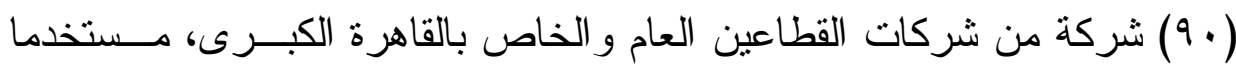

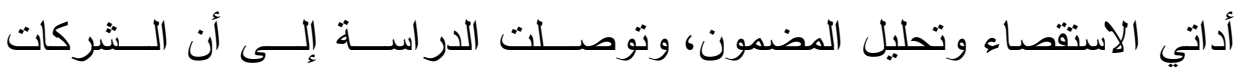

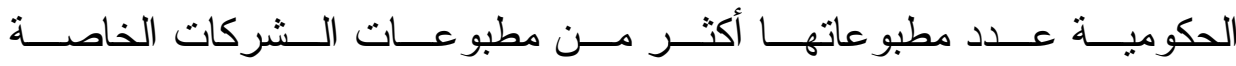

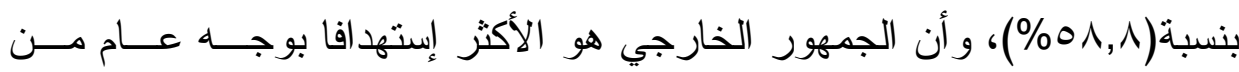

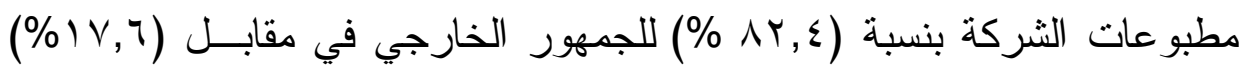

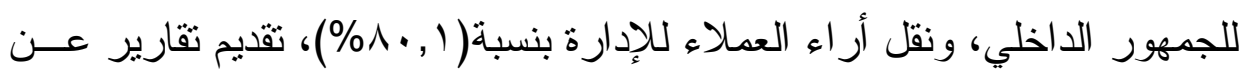

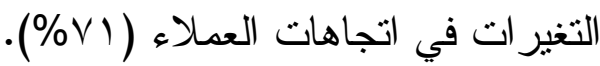

$$
\begin{aligned}
& \text { V }
\end{aligned}
$$

هدفت الدراسة إلي النعرف علي طبيعة نشاط المؤسسات البيئية الحكومية

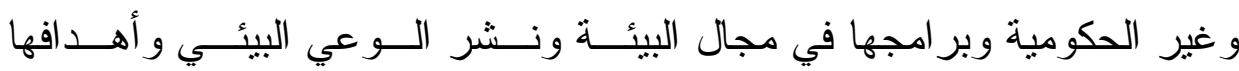

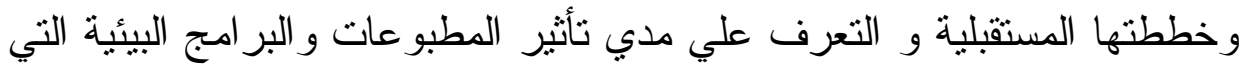
تصدرها المؤسسات و الهيئات الحكومية وغير الحكومية، و إعتمدت علـي عينـــة

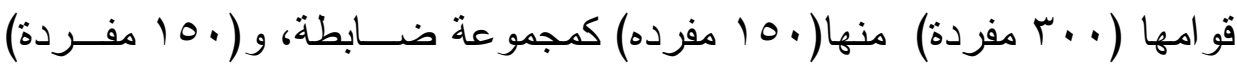

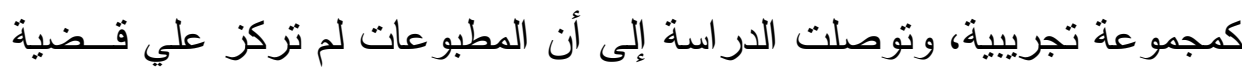

المجلد الرابع


بعينها ولكن تتوعت القضايا و المشكلات، وكانت المعلومات بـسيطة وســـحية

غير أنها ضعيفة من حيث المضمون، وتدني مستوي الوعي لدي الــشباب قبــلـ البرنامج، وضعف التعاون بين المؤسسات البيئية و المؤسسات الإعلامية بالدولـــة

$$
\text { في مجال نشر الوعي البيئي. }
$$

$$
\text { 1 - در اسة سينثيا كلارك( ( ب... }
$$

هدفت الدر اسة إلي التعرف على العلاقة بين الاتصـال الفعــال للعلاقــات

العامة للشركات و المسئولية الاجتماعية لهذه الثركات وتحسين نوعيــة العلاقـــة بين المنظمة وجمهور ها، و التعرف على المشكلات و القضايا البيئية و الاجتماعية، و إعتمدت الدر اسة على المنهج المقارن، وتوصلت إلى أن المشكلات و القــضايا البيئية والاجتماعية تؤثر على القدرة التتافسية للمنظمة، و أيضـا تطوير أسـلوب الاتصـال بالمجتمع عن طريق العلاقات العامة داخل المؤسسة يؤدى إلــى بنـــاء

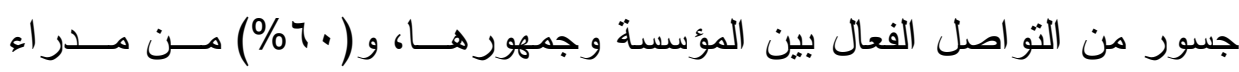
العلاقات العامة يرون ضرورة تعلم المهار ات الإتصالية للعاملين لتعزيز جسور

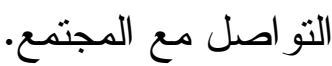

\section{- التعقيب على الار اسات السابقة:}

ا. اطلع الباحث علي ^ در اسات لم تكن علي شركات المياه مباشرةً ولكنهــا تتاولت دور العلاقات العامة ومسئوليتها الاجتماعية تجاه المجتمع المحلي. r. الدر اسات التي تتاولت المسئولية الاجتماعية للعلاقات العامة أثنتت أهميــة

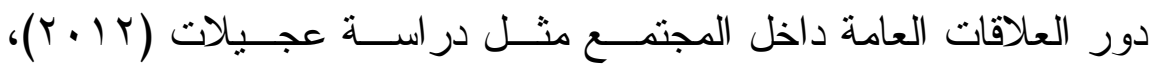

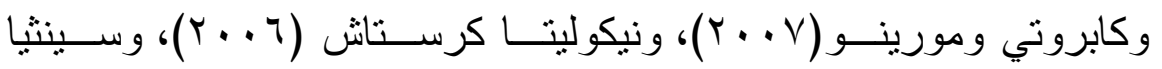

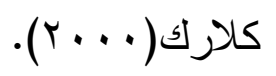


r. أثنتت نتائج هذه الدر اسات منل در اسة نيكوليتا كرسـتاش (T . . Y) مـدى

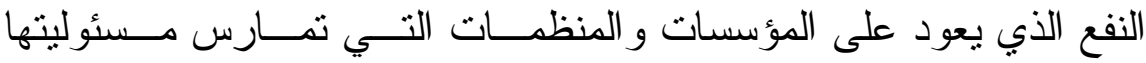
الاجتماعية تجاه القضايا و المشكلات البيئية كرفع نسبة أرباح الثركة وقلة الثرالي

ع. إستخدمت بعض الدراسات منهج المسح و إعتمدت على أداة الاستبيان و أداة

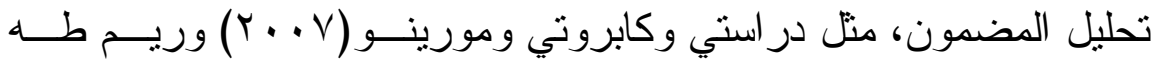

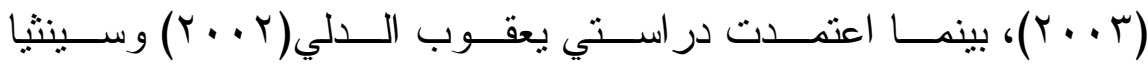

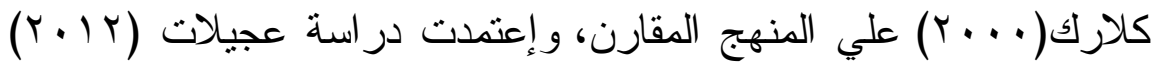
علي منهج در اسة الحالة. ه. ركزت الدراسات على الدور الذي تقوم بـه العلاقــات العامــة فــي بنــاء

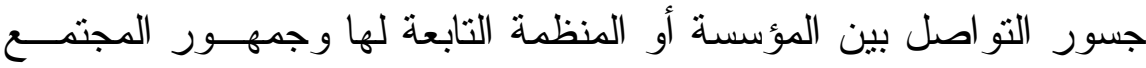

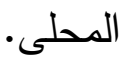
T. تتاولت الدراسات الدور الفعال للعلاقات العامة في تغيير سياسة الــشركات من الربح فقط إلى الربح وخدمة المجتمع المحلى. V. أنثارت بعض الدر اسات إلي وسائل الاتصـال في العلاقـــات العامــة مثـلـل

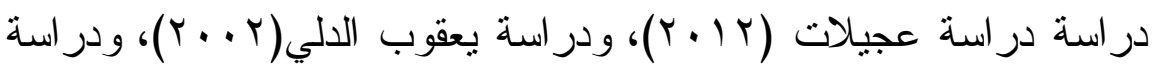
سينتيا كلارك (ب... (Y). - أوجه الاستفادة من الار اسات السابقة: إستفاد الباحث من الدراسات السابقة في تحديد مـشكلة البحــث ونوعهـــا ومنهجها وفروضها ومر اجعها، وتحديد عبار ات أداتي البحث. 
يسعي هذا البحث إلي اختبار الفروض البحثيه التالية: ا-توجد فروق ذات دلالة إحصائية بين إستجابات عينة الدر اسة من ممارسـي العلاقات العامة بشركات مياه الشرب و الصرف الصحي بالدلتا نحو الـدور الذي يقومون بـه تجاه المجتمع المحلي. r-توجد فروق ذات دلالة إحصائية بين إستجابات عينة الدر اسة من جمهــور المجتمع المحلي بالدلتا نحو دور العلاقات العامة بــشركات ميــاه الــشرب و الصرف الصحي تجاه هذا المجتمع. س-توجد علاقة إرنباطية ذات دلالة إحصائية بين إستجابات ممارسي العلاقات العامة و إستجابات جمهور المجتمع المحلي نحو دور العلاقات العامــة فــي مو اجهة قضايا المجتمع المحلي • - الإجراعات المنهجية للبحث

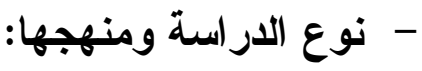
تعتبر هذه الدر اسة من الدر اسات الوصفية التــي تعتـــــ علــي المــنهج الوصفي باعتبارة أنسب مناهج البحث لهذه الدر اسة.

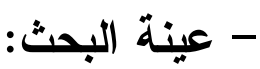
تم أخذ عينة عشوائية من ممارسي العلاقــات العامــة بــشركات ميــاه الثرب و الصرف الصحي ببعض محافظات الدلتا قو امها ( • ع) مفــردة، و عينــة من جمهور المجتمع المحلي لهذه الــشركات قو امهــا (ب (ب) مفــردة ومقـسمة كالتالي: 
جدول (1)

توزيع مفردات عينة الدراسة من ممارسي العلاقات العامة

\begin{tabular}{|c|c|c|c|c|c|}
\hline \multicolumn{6}{|c|}{ وجمهور المجتمع المحلي } \\
\hline \multicolumn{2}{|c|}{ جمهور المجتمع } & \multicolumn{2}{|c|}{ ممارسي العلاقات } & \multirow{2}{*}{ إبــــــــــــــم الثركة } & \multirow[b]{2}{*}{ r } \\
\hline أنسبة & العدد & النسبة & العدد & & \\
\hline$r, r$ & VY & r. & ir & شركي بالدقهلية الــشرب والــــرف & 1 \\
\hline 19,1 & T纟 & r. & $\wedge$ & شالصحي بكفر الشيخ الـشرب و الــــرف & r \\
\hline $19, r$ & r & $1 \mathrm{~V}, 0$ & $\mathrm{v}$ & الصحي بالغربيه الـــشرب و الــصرف & r \\
\hline $1 v, T$ & ov & 10 & 7 & شركية بدميـاه الــشرب و الــصرف & $\varepsilon$ \\
\hline rI, & $\uparrow$ & $1 V, 0$ & $\mathrm{v}$ & شالصركي بالشـرقية الـشـرب و والــــرف & 0 \\
\hline $1 \cdots, \cdot$ & Tr & $1 \cdots, \cdot$ & $\varepsilon \cdot$ & o منظمات & الاجمالي \\
\hline
\end{tabular}

- أداتا الدراسة:

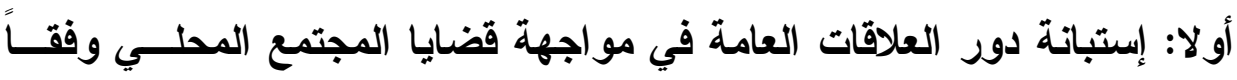
لأراء الممارسبين:

- خطوات إعداد الإستبانة :

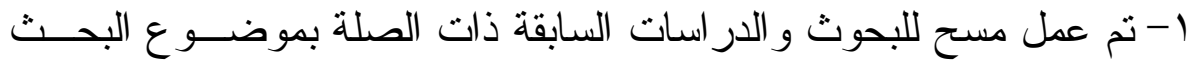

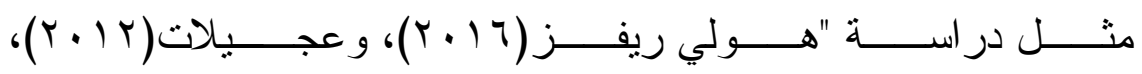

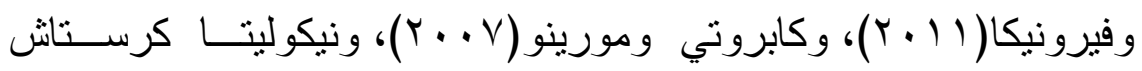




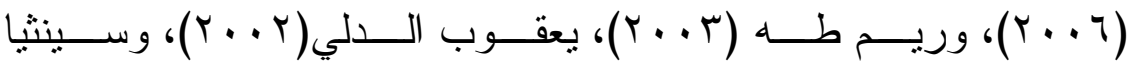

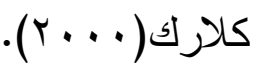

r- مقابلة ممارسي العلاقات العامة بشركات مباه الثرب و الصرف الـصحي للتعرف علي أدو ارهم وأنشطتهم في خدمة المجتمع المحلي. ب- تقسيم الإستبانة إلي مجموعة من الأبعاد ووضع مجموعة من العبـار ات

$$
\text { ل اكل بعد. }
$$

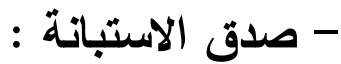

تم عرض الإستبانة على عدد سبعة محكمين من الأساتذه المتخصــصنين في علوم الاعلام و العلاقات العامة (')وتم تعديل ماإتقق علية عدد ستة محكمين،

$$
\text { بما يمنل نسبة اتفاق ( ) }
$$

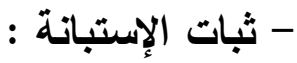

تم تطبيق الاستبانة علي عينة قو امها (•r)مفردة من ممارسي العلاقـات العامة بشركات مياه الثرب و الصرف الصحي، وتم حساب الثبات بطريقة ألفـــا : (1) - أ.د/ علي عجوة: الاستاذ المنقرغ بقسم العلاقات العامة و الاعلان بكلية الاعلام - جامعة القاهرة. - أ.د/ محمود يوسف: أستاذ العلاقات العامة و الاعلان بكلية الاعلام - جامعة القاهرة.

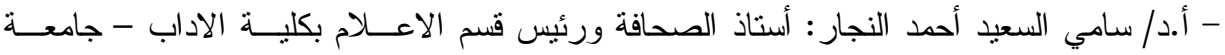
المنصورة.

- أ.د/ سامي طايع: أستاذ العلاقات العامة و الاعلان بكلية الاعلام - جامعة القاهرة.

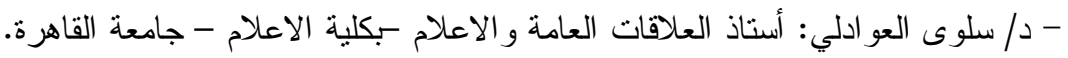

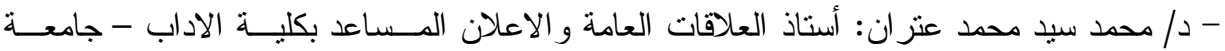

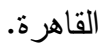

- د/ نرمين خضر : أستاذ الاعلام الدولي بكلية الاعلام - جامعة القاهرة. 
كرونباخ Cronbach's Alpha حيث جاء دال عند مـستوب دلالــــ(0.825)، وهي قيمة دالة عند مستوي دلالة (0.01) و هذا يدل علي ثبات دال الأداه.

ثانيا: إستبانة دور العلاقات العامة في مواجهة قضايا المجتمع المحلي وفقاً لأر اء

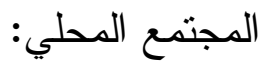

- خطوات إعداد الاستبانة :

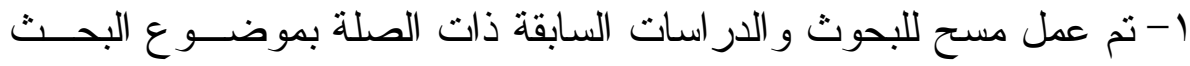

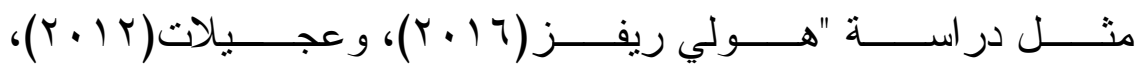

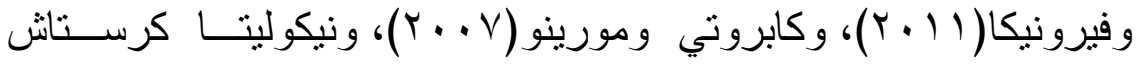

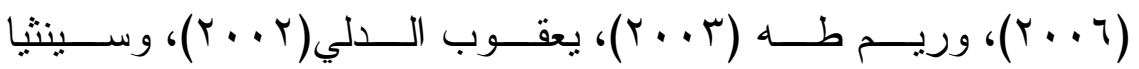

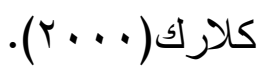

r- تقسيم الإستبانة إلي مجموعة من الأبعاد ووضع مجموعة من العبـار ات

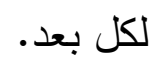

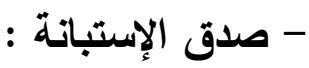

تم عرض الاستبانة على المحكمين السابقين ونم تعديل ماإتقق علية عـدد

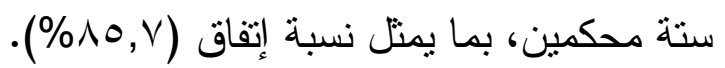

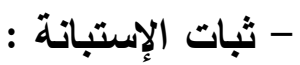
تم تطبيق الإستنبانة علــي عينــة قو امهــا (roم)مفـردة مــن جمهـور

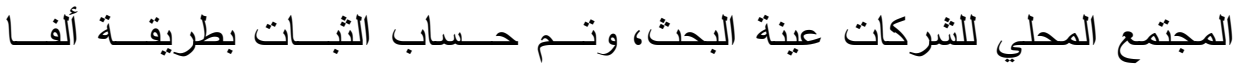

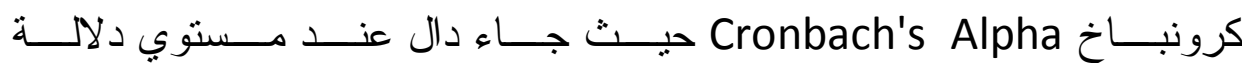

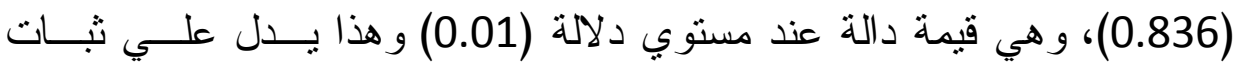




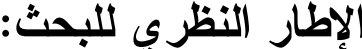

"العلاقات العامة و المسئولية الاجتماعية تجاه قضايا المجتمع المحلي"

أولاً: ماهية العلاقات العامة:

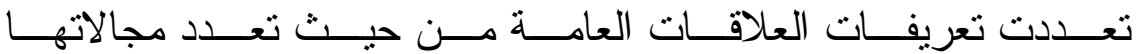

و أنثطنها و أدو ار ها، فالعلاقات العامة تهدف إلى صياغة وتحديد سياســة دائمسـة

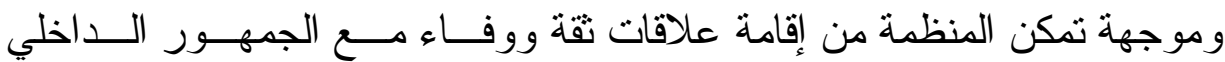
و الخارجي، ووجود إستمر ارية المنظمة مر هون بهذه الجماهير ، وعلى هذا الأساس

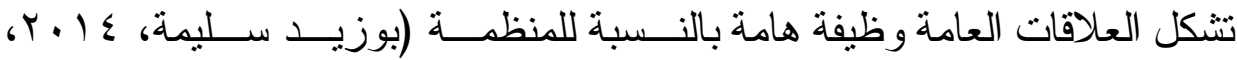

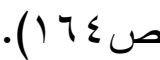
ثانيا: وظائف العلاقات العامة:

تعددت الأبحاث و الدر اسات التي وققت علي وظــائف و أدوار العلاقــات

العامة، وتحددت أدوار ووظائف العلاقات العامة كالاتي (على عجوة وكريمـان

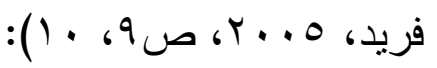

1- الوظائف الإعلامية: "توعية جمهور المنظمة بمخرجاتها (سلعا وخدمات)، وتظوير تقنبات الأنشطة الإعلامية مع جمهور المنظمة.

ז-وظائف الاستعلام: "إجر اء البحوث المسحية لجمهور المنظمــة، وتحليـلـل

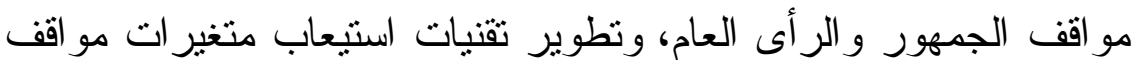

$$
\text { الجمهور ( حاجاتة ورغباتة ). }
$$

r- وظائف التتسيق: " ربط خطة العلاقات العامة مع خطط الإدارات العليــا،

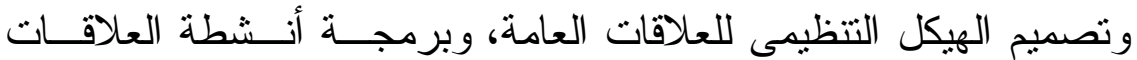
العامة، تتسيق فعاليات المتابعة و المر اقبة. 
- وهنائ بعض الدر اسات قسمت وظائف العلاقات العامة كالتالي:

1- البحث: تقوم العلاقات العامة بجمع وتحليل وبحث ودر اسة اتجاهات الر أي العام لجماهير المؤسسة أو الهيئة، ومعرفة آرائهم و اتجاهاتهم (محمد فلحي،

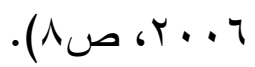

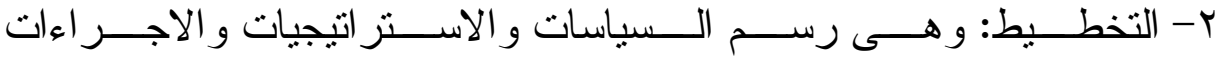

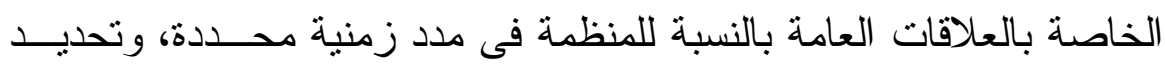

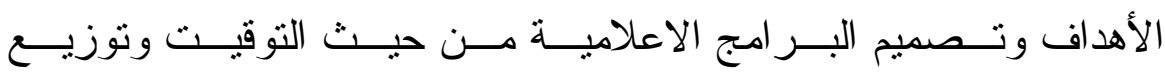
الاختصاصات على الخبر اء وتحديد الميز انية تحديدا دقيقا (محمـــــــلهل،

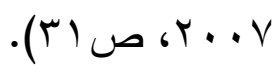

r- التنسيق: العمل على الاتصال بالمسئولين و العملاء الداخليين، وكذلك الاتصال بالعملاء الخارجيين لتبادل الاخبار و المعلومات و النصائح المتعلقة بالعلاقات العامة، وهى التى تؤثر فى إسم المنظمة وشهرتها (محمد هلا،

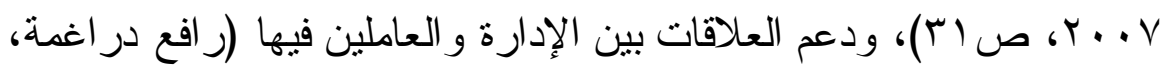

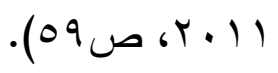

ع- الاتصال: يعني القيام بتتفيذ الخطط والاتصال بالجماهير المستهدفة، وتحديد الوسائل الإعلامية المناسبة لكل جمهور، وعقد المؤتمرات، و إنتاج الأفلام

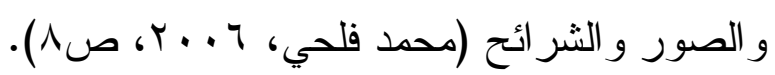

0- التقويم: ويقصد به قياس النتائج الفعلية لبر امج العلاقات العامة ، و القيام

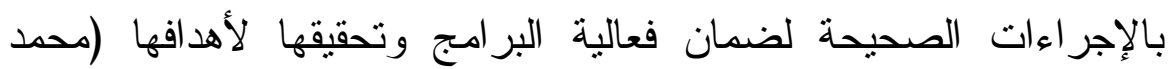

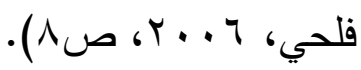


7- المسئولية الاجتماعية:

لقد تطور إهتمام العلاقات العامة داخل المنظمات بالمجتمع المحلى فى العصر الحديث تطور املحوظا، ففى بداية القرن العشريين كان دور العلاقات

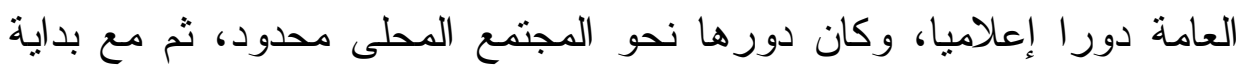
الخمسينيات بدأت مرحلة المسئولية الاجتماعية للعلاقات العامة وبدأ هذا الدور

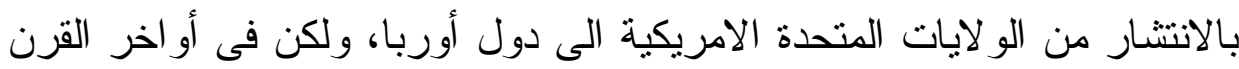
العشرين جاء دور جديد للعلاقات العامة وهو مر اقبة البيئة بالاضافة الى دورها الاساسي وهو المسئولية الاجتماعية تجاه المجتمع المحلى، ولذلك فالمسئولية الاجتماعية للشركات هي: مفهوم يمكن من خلاله للشركات دمج الاهتمامات

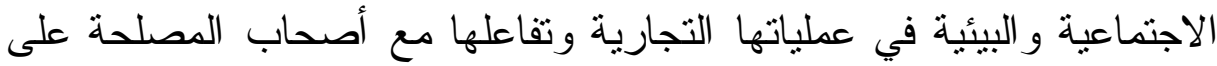
أساس تطوعي. - مبادئ المسئولية الاجتماعية للشركات:

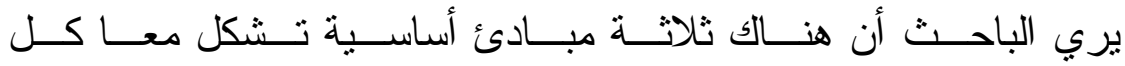
نشاط المسئولية الاجتماعية للشركات وهي: الاستدامة و المساءلة و الثفافية.

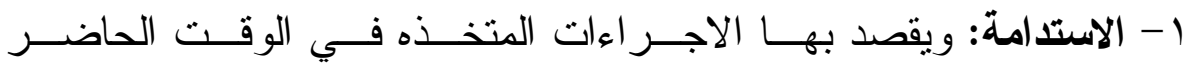

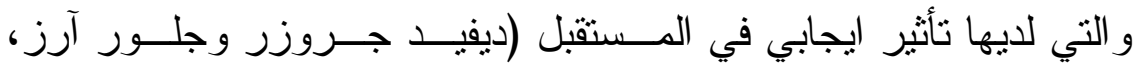

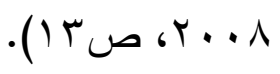
r- المسائلة: هي الإعتر اف بالمسئولية عن الأفعال و المنتجـــات و القـــرارات و السياسات وتحملها، وتتضمن الإدارة و الحوكمة و التتفيذ في نطاق الــدور

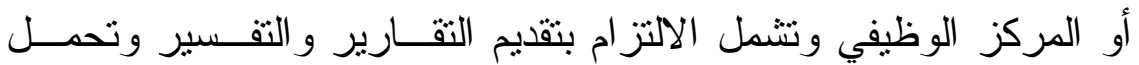

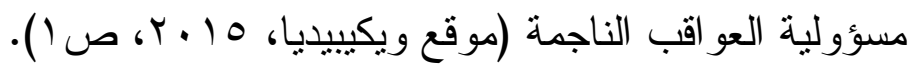

المجلد الرابع


r- الثفافية: هى أن نقوم المنظمة بالاعلان و الافصاح عن جميع المعلومات

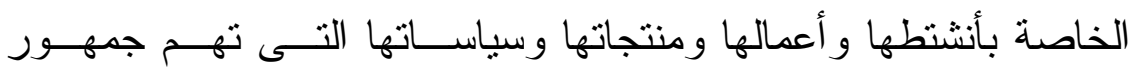
المجتمع المحلى الذى تعيش وتتو اجد فيه المنظمة، بشكل و واضح وصنئ وصريح

$$
\text { وبدون تزييف. }
$$

- دور العلاقات العامة فى تفعيل المسئولية الاجتماعية للمنظمات:

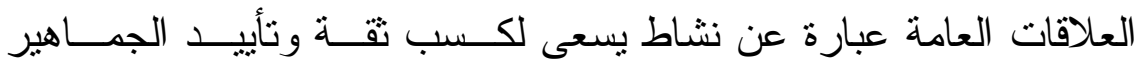

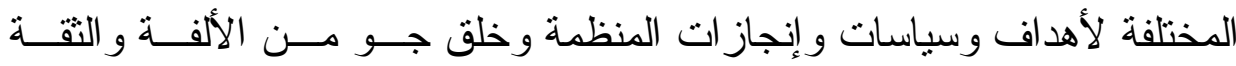
و التعاون بين المنظمة وجماهير ها الداخلية والخارجية، فهذا الجمهور هو ماتعتمد

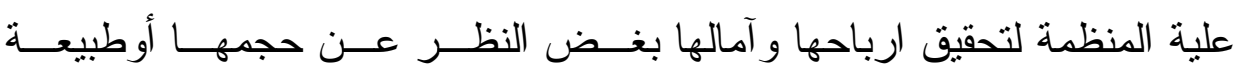
عملها. ولذلك فالمشكلة أن العديد من الثركات وضعت أهدافها فى الثراء و الربح دون الاهتمام بإحتياجات المجتمع المحلى الذى تعيش فيه تلك الثركات، فوجدت

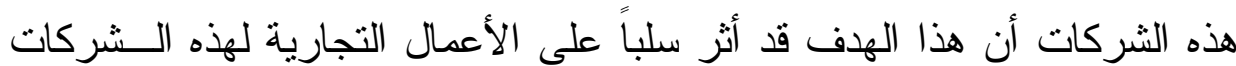

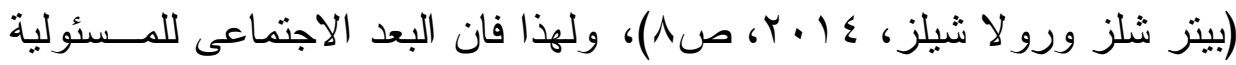
الاجتماعية للشركات يتمثل في (المـسئولية تجــاه العهــلاء، المسـئولية تجــاه الموظفين، المسئولية تجاه المجتمع). - الاتجاهات الحديثة للمسئولية الاجتماعية للعلاقات العامة: تعددت الإتجاهات الحديثة عن دور الثركات و المنظمات المعاصرة فـي

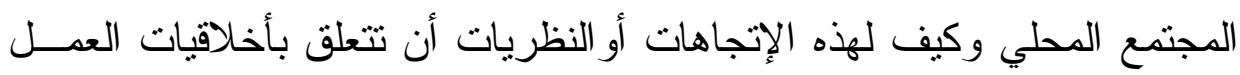
و المسئولية الاجتماعية للشركات كالتالي:

المجلد الرابع


1-نظرية العقد الاجتماعى" Social Contract Theory "إيان ديفيس":

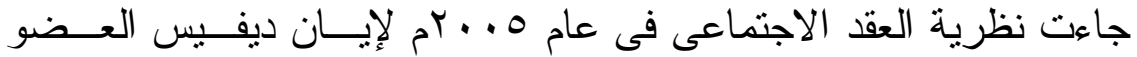
المنتندب لثركة " ماكينزى ديفيس" و التى يقصد بها اعطاء المنفعة المنبادلة بــين الفرد و الجماعة و المجتمع ككل، بشرط أن يعرف كل طرف حقوقـــة وو اجباتـــة

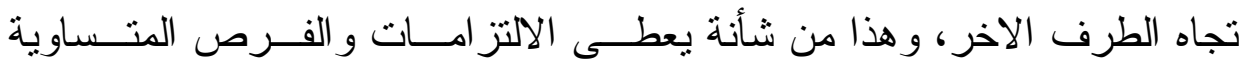

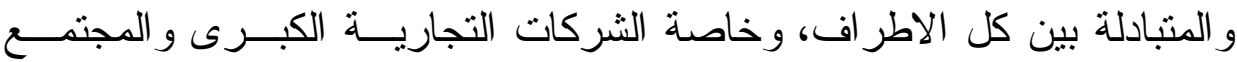

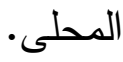

ووقفت هذه النظرية على المسئولية الاجتماعية للشركات محدودة للغايــة،

فقد تحتاج الاعمال التجارية الكبرى الى التعبير الى حد كبير عن مساهتها فـى التى

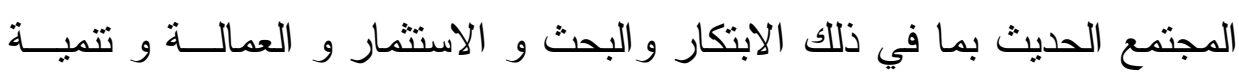

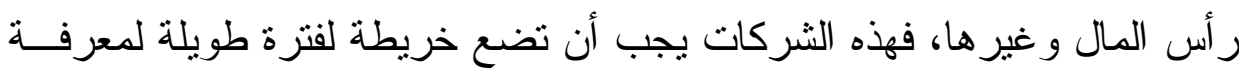
الخيار ات وردود الافعال فى ظل الضغوط الاجتماعية كجز هـــن اســتر اتيجية

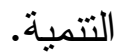

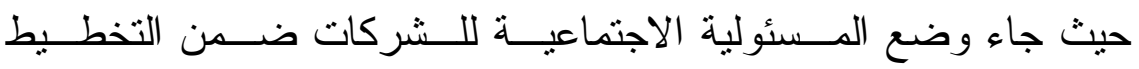
الاستر اتيجى الثامل فى الثركة، وذلك لمناقثة القضايا الاجتماعية فى الــشركة

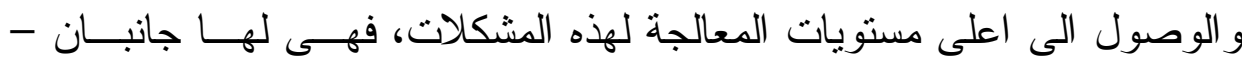

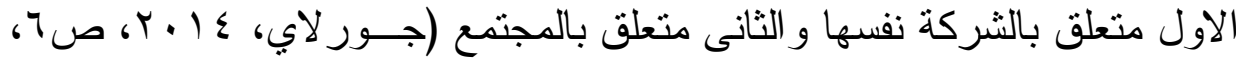
r - نظرية تكامل المشاركة الخارجية لجون براون وروين نوتال: تركز هذه النظرية على جهود الثركة لإدارة شئونها لتوطيد العلاقة مــع

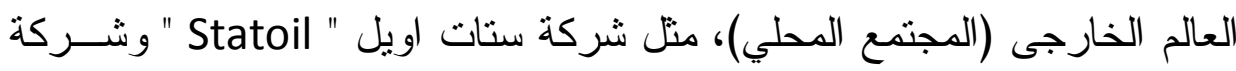

المجلد الرابع


يونيليفر " Unilever " التى أخذهم المؤلفين كأمثلة رائدة للشركات التجارية التى تعتمد على المشاركة الخارجية.

فعلى ســبيل المثــال شــركة يـــنيليفر " Unilever " التــى اعتمــدت

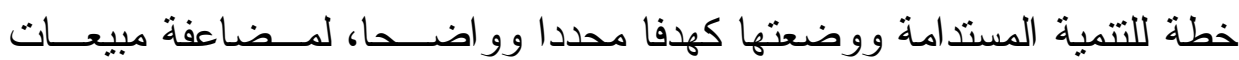
الثركة وتقليل التأثير السلبى على البيئة، وزيادة الايجابيـــة الاجتماعيـــة مثـــل

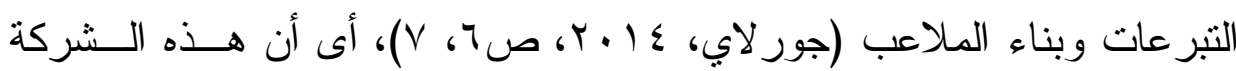
قامت بما يسمى بتكامل المشاركة الخارجية مع المجتمع المحلي، فاعتمادها علي

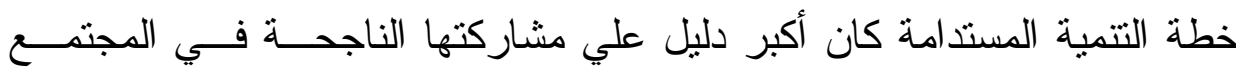
المحلي.

\section{r-نظرية أصحاب المصلحة " Stakeholder theory"}

الاهنمام بدر اسة علاقات المنظمة مع مجموعات المصالح منذ منتــف

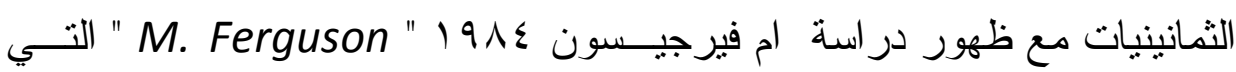
أثنارت الي ضرورة تطوير التوجهات النظرية في مجال العلاقات العامة بحيــث يتم التركيز علي در اسة العلاقات في حد ذاتها سو اء بين المنظمة وجماهير ها أو بين المنظمات وبعضها البعض بل وبــين المنظمــة و المجتمــع نفـسه (انجـي

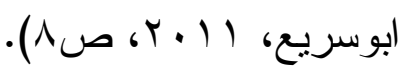

و لابد من التفاعل بين المنظمة و أصحاب المصالح فيما يتعلــق بالمنفعــة المتبادلة لكلا الطرفين، ولهذا فإن العلاقات العامة للمنظمات المعاصــرة تقـوم بدور فعال تجاه المجتمع المحلى الذي تعيش فيه تلك المنظمات، و ولهذا جــاءت

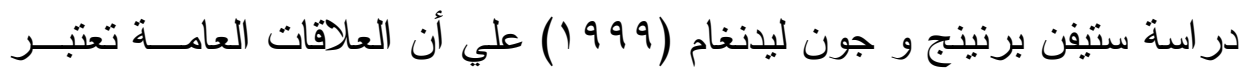
حلقة الوصل بين أي منظمة و المجتمع الذي يحيط بها. 
ثالثاً: وسائل إتصال العلاقات العامة بالمجتمع المحلي:

العلاقات العامة فى أي منظمة تقوم بعملية إتصال ثنائي الإتجاه بين

المنظمة و المجتمع المحلي كالتالي؛

أ): الاتصال الصادر من المنظمة الي المجتمع المحلي و الذي يقوم علي إعلام

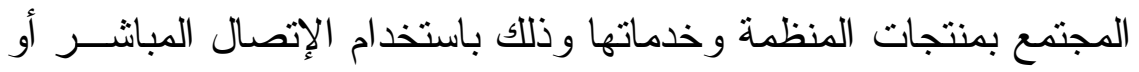

الاستعانة بوسائل الإعلام المختلفة.

ب): الاتصال الصادر من المجتمع المحلي إلي المنظمة وينتم فيـــه نقــلـ آر اء

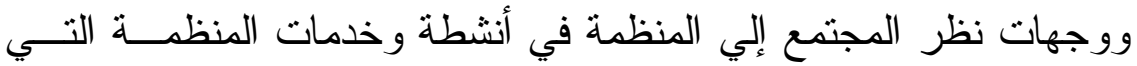

$$
\text { تقدمها. }
$$

\section{• عناصر عملية الاتصال في العلاقات العامة :}

- المرسل: هو ممارس العلاقات العامة و الذي يقـوم بتقـــيم الرســالة الــي جمهور المنظمة سو اء الداخلي أو الخارجى ( المجتمع المحلى ).

$$
\text { - المستقبل: هو جمهور المنظمة الداخلي و الخارجى. }
$$

- الرسالة : وهي المضمون الذي يقوم ممارس العلاقات العامة بإرسالة الــي

$$
\text { جمهور المنظمة. }
$$

- الوسيلة : تقوم العلاقات العامة بتحديد الوسيلة الاتصالية المناسبة للرســالة

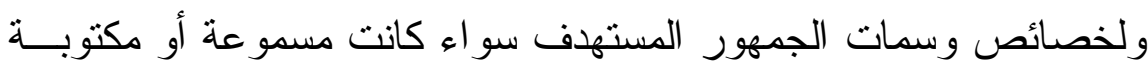

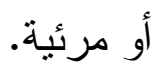

- رجع الصدي : وهي إعادة إرسال الرسالة من المستقبل إلى المرسل. 
رابعاً: جمهور العلاقات العامة:

أ- الجمهور الداخلى: وهو عبارة عن كافة الموارد البشرية بالمنظمة، وهــو

هدف أساسى للعلاقات العامة في تركيز بر امج النوعية عليه، حيث تعتبر

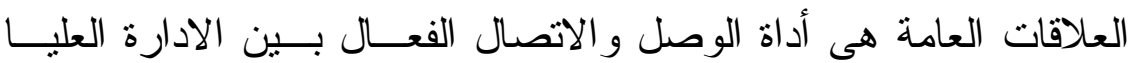

وجمهور العاملين داخل المنظمة.

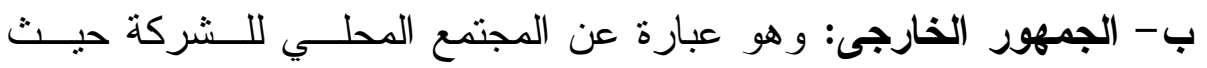

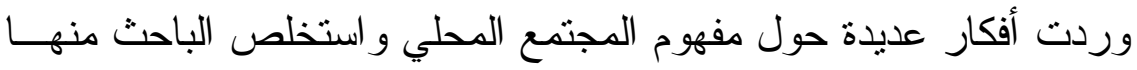

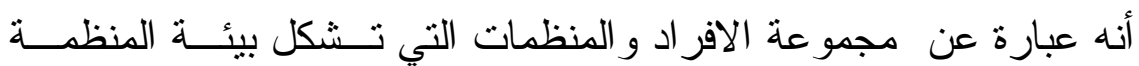
وتحيط بها ، و التي من شأنها إقامة علاقة جيدة معها بما يعـود بالفائسدة

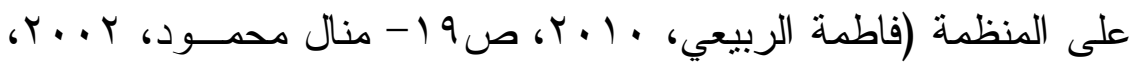

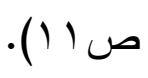

- نتائج الاراسة الميدانية:

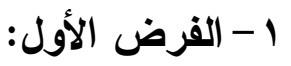

توجد فروق ذات دلالة إحصائية بين إستجابات عينة الدراسة من ممارسي

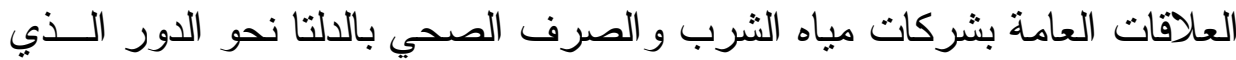
يقومون به تجاه المجتمع المحلي.

للتحقق من صحة هذا الفرض إستخدم الباحث إختبار "كا؟" لمعرفة دلالـــة

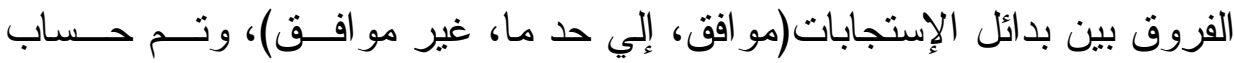

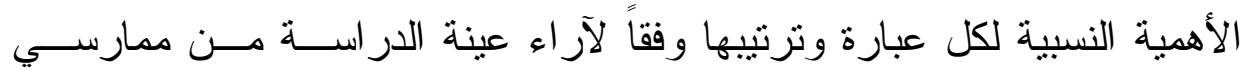
العلاقات العامة البالغ عددهم (• ع)مفردة، ويمكن تتاول النتائج كما يلي: 


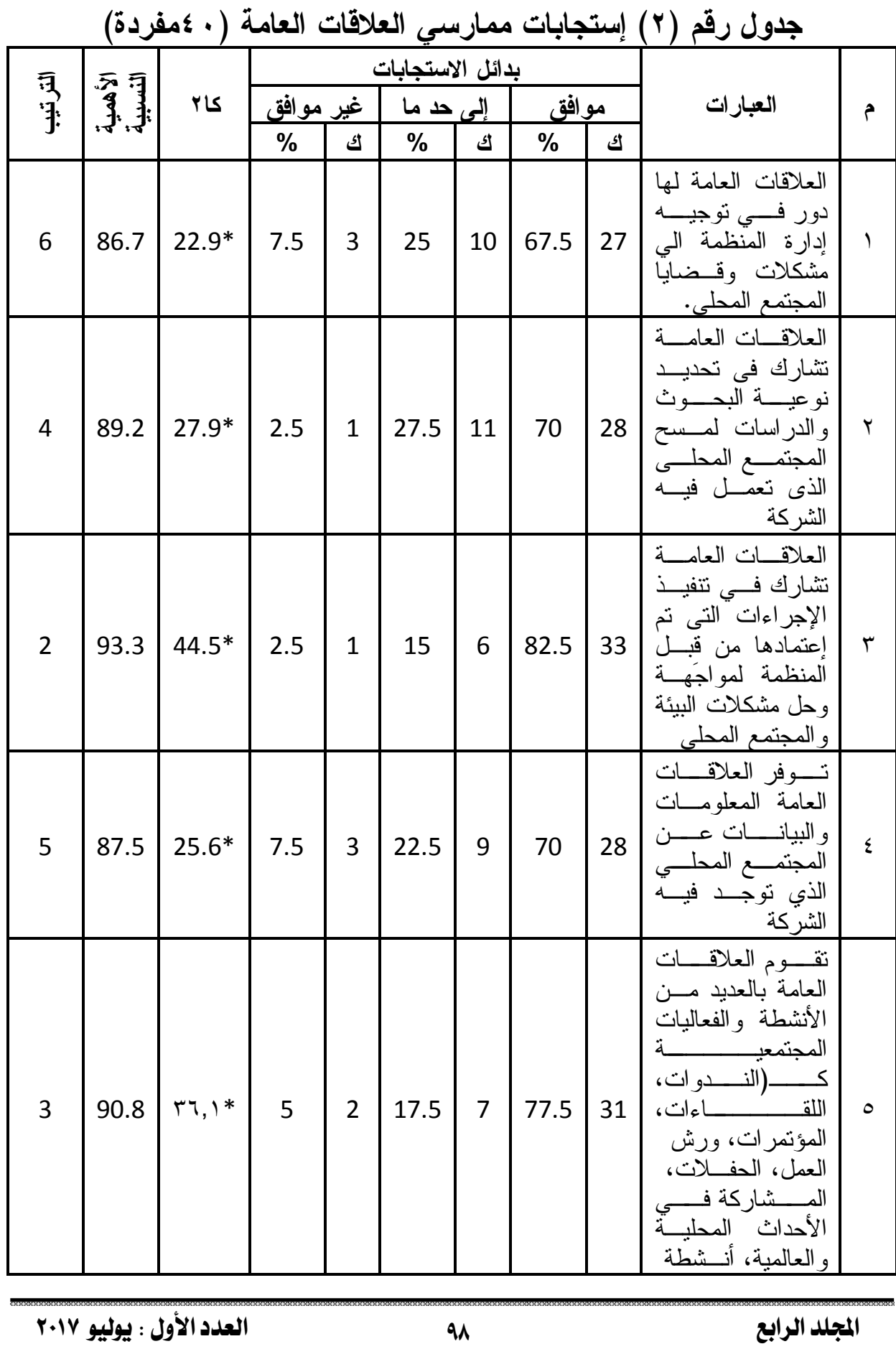




\begin{tabular}{|c|c|c|c|c|c|c|c|c|c|c|}
\hline \multirow{3}{*}{ 牙。 } & \multirow{3}{*}{ 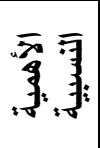 } & \multirow{3}{*}{ كاr } & \multicolumn{6}{|c|}{ بـائل الاستجابات } & \multirow{3}{*}{ العبارات } & \multirow{3}{*}{ r } \\
\hline & & & \multicolumn{2}{|c|}{ غير موافث } & \multicolumn{2}{|c|}{ إلى حـ ما } & \multicolumn{2}{|c|}{ مو افق } & & \\
\hline & & & $\%$ & ك & $\%$ & ك & $\%$ & ك & & \\
\hline & & & & & & & & & 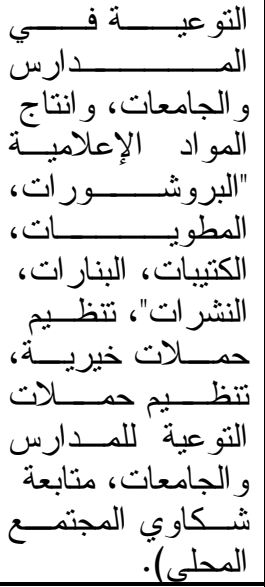 & \\
\hline 1 & 95.8 & $22.5^{*}$ & 0 & 0 & 12.5 & 5 & 87.5 & 35 & 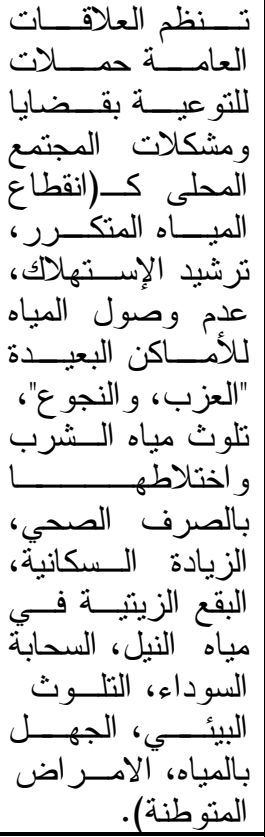 & 7 \\
\hline 9 & 65.8 & 1.6 & 30 & 12 & 42.5 & 17 & 27.5 & 11 & 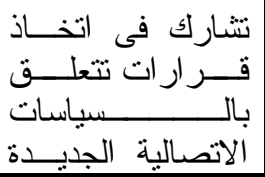 & $\vee$ \\
\hline
\end{tabular}




\begin{tabular}{|c|c|c|c|c|c|c|c|c|c|c|}
\hline \multirow{3}{*}{ 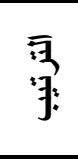 } & \multirow{3}{*}{ 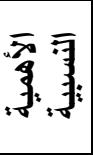 } & \multirow{3}{*}{ Sاr } & \multicolumn{6}{|c|}{ بدائل الاستجابات } & \multirow{3}{*}{ العبار ات } & \multirow{3}{*}{ p } \\
\hline & & & \multicolumn{2}{|c|}{ غير موافتي } & \multicolumn{2}{|c|}{ إلى حـ ما } & \multicolumn{2}{|c|}{ مو افق } & & \\
\hline & & & $\%$ & 5 & $\%$ & ك & $\%$ & ك & & \\
\hline & & & & & & & & & 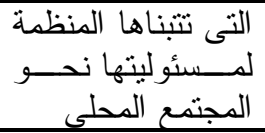 & \\
\hline مكرر 4 & 89.2 & $31.9 *$ & 7.5 & 3 & 17.5 & 7 & 75 & 30 & 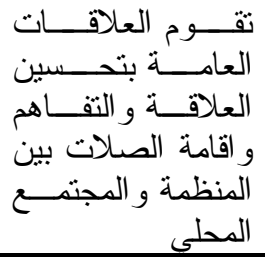 & $\wedge$ \\
\hline 8 & 81.7 & $13.4^{*}$ & 15 & 6 & 25 & 10 & 60 & 24 & 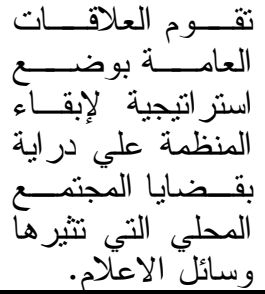 & 9 \\
\hline 7 & 85.0 & $21.4^{*}$ & 12.5 & 5 & 20 & 8 & 67.5 & 27 & 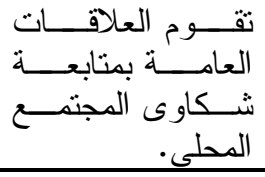 & $1 \cdot$ \\
\hline 11 & 54.2 & 9.9 & 47.5 & 19 & 42.5 & 17 & 10 & 4 & 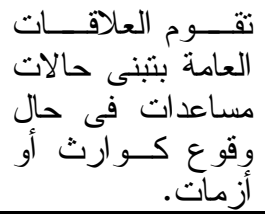 & 11 \\
\hline 10 & 61.7 & 2.1 & 37.5 & 15 & 40 & 16 & 22.5 & 9 & 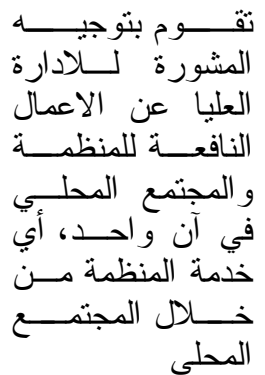 & ir \\
\hline & & & & & & & & & & \\
\hline
\end{tabular}




\section{يتضح من نتائج الجدول السابق ما يلي :}

جاءت إستجابات عينة الدر اسة من ممارسي العلاقات العامــة بــشركات مياه الثرب و الصرف الصحي بمحافظات الدلتا "الدقهلية، كفر الثيخ، الغربيــة،

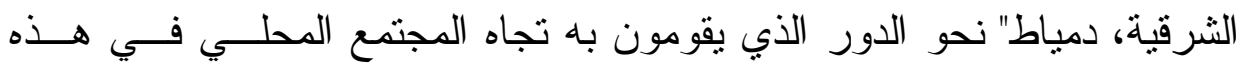

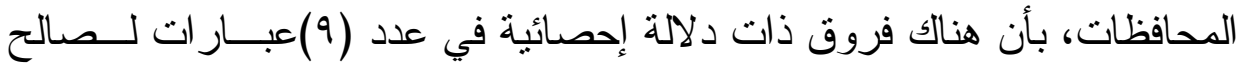

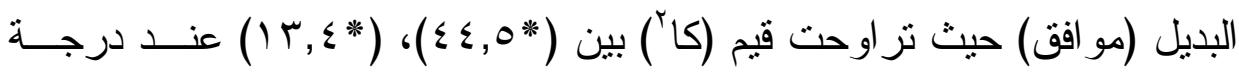

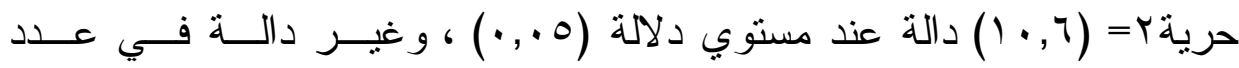

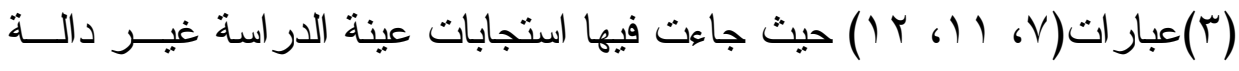

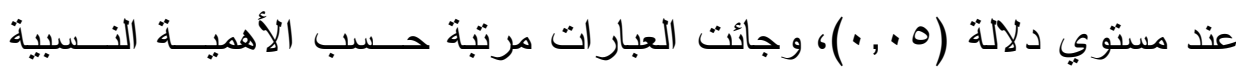
كما يلي : - مان

- في الترتيب الاول العبارة رقم (7): "تنظم العلاقات العامة حملات للتوعية بقضايا ومشكلات المجتمع المحلى كـ(إنقطاع المياه المتكرر، ترشيد الإستهلاك، عدم وصول المياه للأماكن البعيدة "العزب، و النجوع"، تلوث مياه الثرب و اختلاطها بالصرف الصحي، الزيادة السكانية، البقع الزيتية

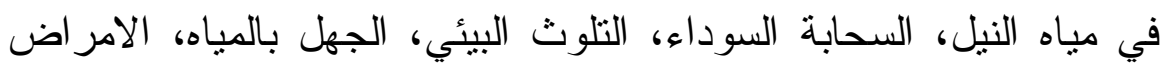

$$
\text { المتوطنة)" حيث بلغت الأهمية النسبية لها (1, 90\%). }
$$

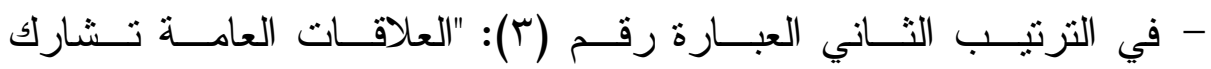

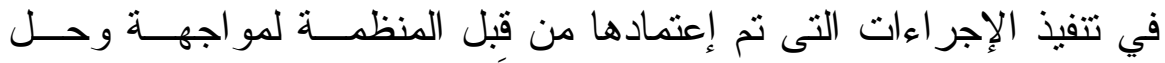

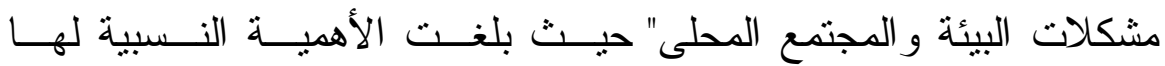
.$(\% q r, r)$ 


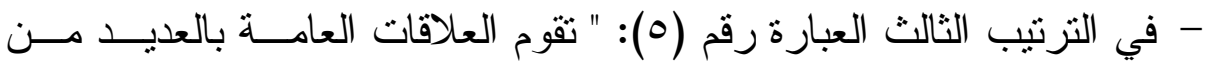

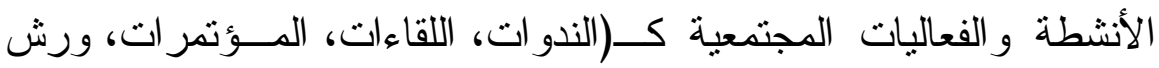

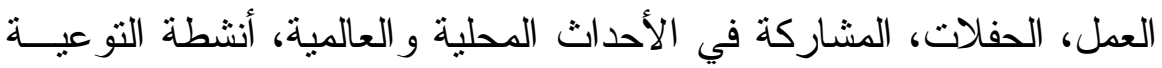

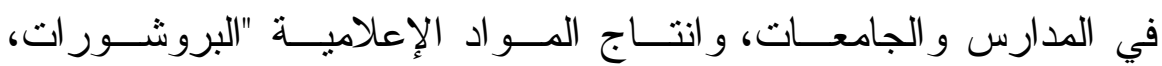
المطويات، الكتيات، البنار ات، النشر ات"، تتظيم حملات خيريـــة، تنظــيم حملات التو عية للمدارس و الجامعات، متابعة شكاوي المجتـــع المحــيـي)" حيث بلغت الأهمية النسبية لها (^, • 9\%).

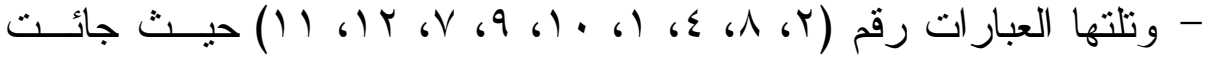

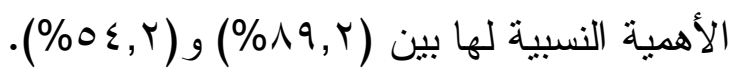

ومن خلال ماسبق قام الباحث بحساب متوسط الأهمية النسبية للعبـارات

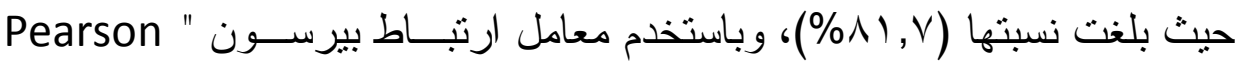
Correlation

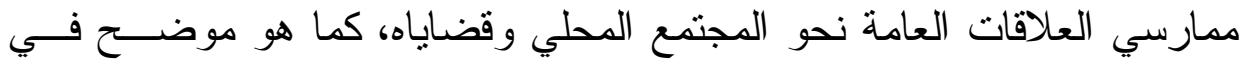

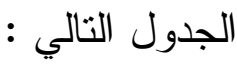

المجلد الرابع




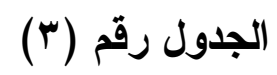

يوضح قيمة معامل إرتباط بيرسون"ر" للعلاقة بين

الموقع الجغرافي لثركات المياه وطبيعة دور ممارسي العلاقات العامة

بها نحو المجتمع المحلي وقضاياه

\begin{tabular}{|c|c|c|c|}
\hline المجتمع المحلي وقضارسين نحو & الثوقعات الجغراهي & & المتغ ل المغ \\
\hline-0.008 & 1 & Pearson Correlation & \multirow{3}{*}{ الثركات المياه } \\
\hline 0.963 & & Sig. (2-tailed) & \\
\hline 40 & 40 & $\mathrm{~N}$ & \\
\hline \multirow[t]{2}{*}{1} & -0.008 & Pearson Correlation & \multirow{3}{*}{ والمجتمع المحلي } \\
\hline & 0.963 & Sig. (2-tailed) & \\
\hline 40 & 40 & $\mathrm{~N}$ & \\
\hline
\end{tabular}

**. Correlation is significant at the 0.01 level (2-tailed).

يتضح من نتائج الجدول السابق أن العلاقـــة بــين (الموقــع الجغرافـي لثركات المياه وطييعة دور ممارسي العلاقات العامة بها نحو المجتمع المحلـي لئي وقضاياه) علاقة عكسية (سالبة) و غير دالة إحصائيا ، حيث بلغت قيمة معامـل لهـل إرتباط بيرسون ( =0.008- ) وهي قيمة سالبة غيردالة عند مسستوي دلالـــة

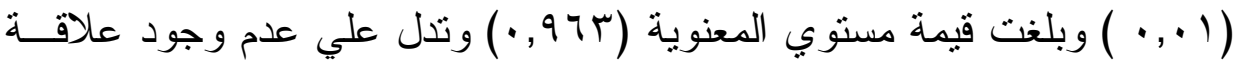
قوية بين المتغيرين. ويعزي الباحث هذه النتيجة إلي إدراك وفهم مفردات العينة إلي طبيعة

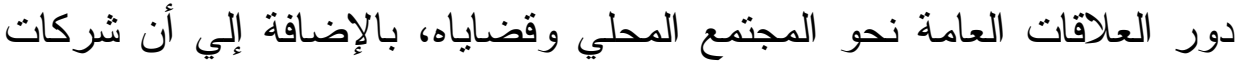
المياه في المحافظات المختلفة تعمل تحت سقف واحد وهو الثركة القابضة لمياه الثرب و الصرف الصحي بجمهورية مصر العربية، فيوجد مستوي كبير من 
التطابق بين الأنشطة والأدوار و الفعاليات المجتمعية التي تقوم بها إدارات

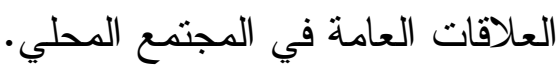

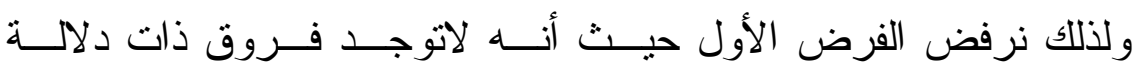
إحصائية بين إستجابات عينة الدر اسة من ممارسي العلاقات العامة بشركات مياه

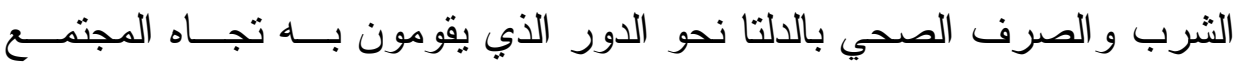
المحلي.

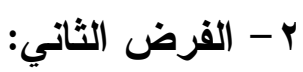

توجد فروق ذات دلالة إحصائية بين إستجابات عينة الدراسة من جمهور

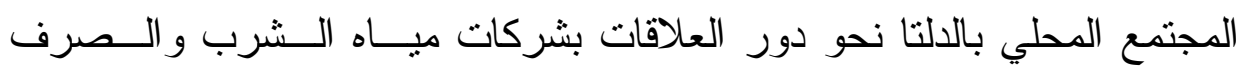

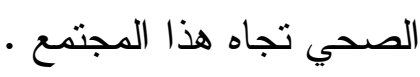

للتحقق من صحة هذا الفرض إستخدم الباحث إختبار "كا؟" لمعرفة دلالـــة

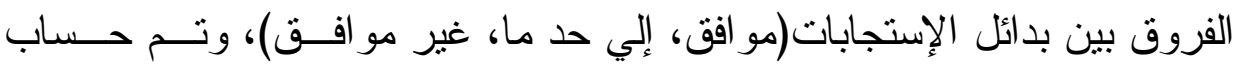

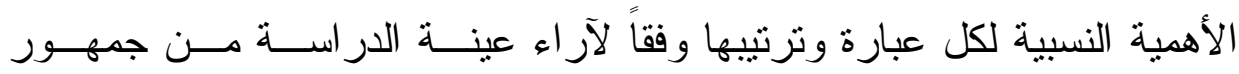

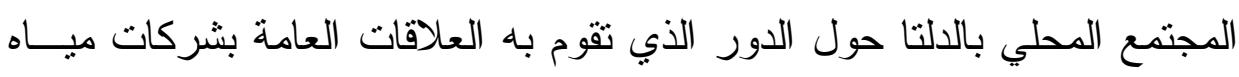

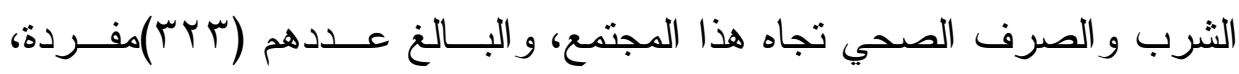
ويمكن تتاول النتائج كم يلي: 
جول رقم (ع)

إستجابات عينة الدراسة من جمهور المجتمع المحلي

\begin{tabular}{|c|c|c|c|c|c|c|c|c|c|c|}
\hline \multirow{3}{*}{ 雪 } & \multirow{3}{*}{ 雨電等: } & \multirow{3}{*}{ كا" } & \multicolumn{6}{|c|}{ بائل الاستجابات } & \multirow{3}{*}{ العبارات } & \multirow{3}{*}{ م } \\
\hline & & & \multicolumn{2}{|c|}{ |غير مو (فق } & \multicolumn{2}{|c|}{ إلى حـ ما } & \multicolumn{2}{|c|}{ 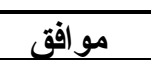 } & & \\
\hline & & & $\%$ & s & $\%$ & ك & $\%$ & S & & \\
\hline 1. & $34 . \wedge$ & or, $\mathrm{r}^{*}$ & 96.3 & 311 & 3.1 & 10 & 0.6 & 2 & 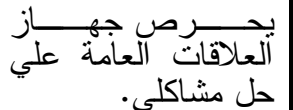 & 1 \\
\hline$\varepsilon$ & 36.3 & $\{v, 1 *$ & 92.9 & 300 & 5.3 & 17 & 1.9 & 6 & 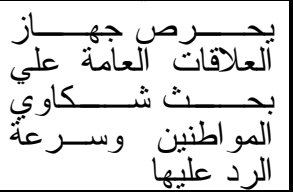 & r \\
\hline 11 & $34 . \mathrm{V}$ & $T, \varepsilon *$ & 96.6 & 312 & 2.8 & 9 & 0.6 & 2 & 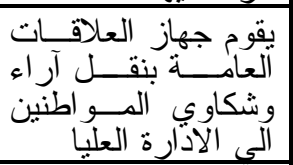 & $r$ \\
\hline$r$ & 40.1 & $\left\{1,7^{*}\right.$ & 86.1 & 278 & 7.4 & 24 & 6.5 & 21 & 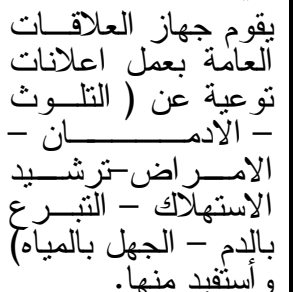 & $\varepsilon$ \\
\hline 。 & 36.1 & ov, $1 *$ & 94.4 & 305 & 2.8 & 9 & 2.8 & 9 & 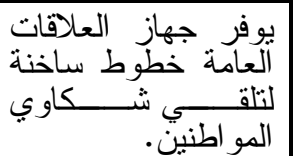 & 0 \\
\hline ir & $34 . r$ & $r \cdot, r^{*}$ & 97.2 & 314 & 2.8 & 9 & 0 & 0 & 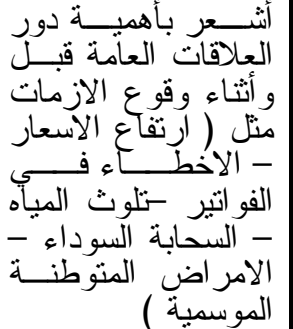 & 1 \\
\hline مكرر & $34 . r$ & $71,0 *$ & 97.5 & 315 & 2.2 & 7 & 0.3 & 1 & 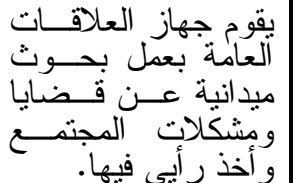 & v \\
\hline
\end{tabular}




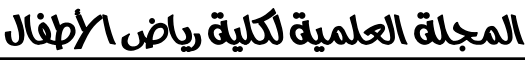

\begin{tabular}{|c|c|c|c|c|c|c|c|c|c|c|}
\hline \multirow{3}{*}{ 浔 } & \multirow{3}{*}{ 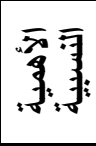 } & \multirow{3}{*}{ كا' } & \multicolumn{6}{|c|}{ بدائل الاستجابات } & \multirow{3}{*}{ العبار ات } & \multirow{3}{*}{ r } \\
\hline & & & \multicolumn{2}{|c|}{ غير مو افق } & \multicolumn{2}{|c|}{ إلى حد ما } & \multicolumn{2}{|c|}{ مو افق } & & \\
\hline & & & $\%$ & ك & $\%$ & ك & $\%$ & ك & & \\
\hline V & 35.7 & $00,9 *$ & 94.7 & 306 & 3.4 & 11 & 1.9 & 6 & 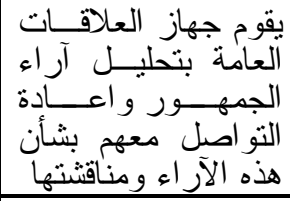 & $\wedge$ \\
\hline$\wedge$ & 35.4 & $09, r^{*}$ & $90, V$ & $r \cdot q$ & $r, 0$ & $\wedge$ & 1.9 & 7 & 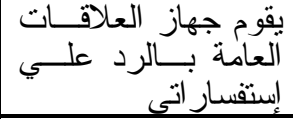 & 9 \\
\hline 1 & 44. V & $r q, r^{*}$ & 78.6 & 254 & 8.7 & 28 & 12.7 & 41 & 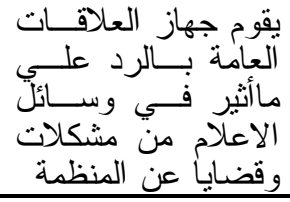 & 1 . \\
\hline r & $40 . \wedge$ & $\varepsilon r, r^{*}$ & 86.4 & 279 & 5 & 16 & 8.7 & 28 & 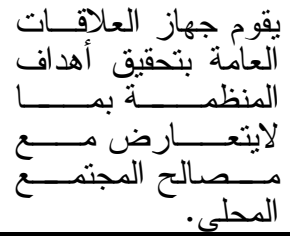 & 11 \\
\hline 7 & 35.8 & $00,9 *$ & 94.7 & 306 & 3.1 & 10 & 2.2 & 7 & 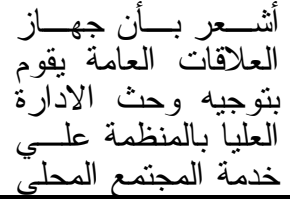 & 12 \\
\hline $1 T$ & 34.1 & $r \cdot, q *$ & 97.8 & 316 & 2.2 & 7 & 0 & 0 & 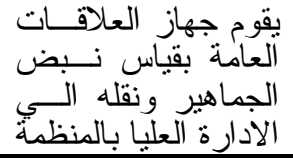 & 13 \\
\hline مكرر & 36.1 & $00, \wedge *$ & 94.1 & 304 & 3.4 & 11 & 2.5 & 8 & 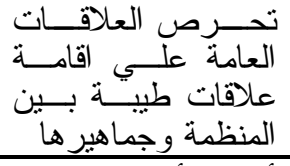 & 14 \\
\hline 9 & $35 . r$ & $o v, 1 *$ & 95 & 307 & 4 & 13 & 0.9 & 3 & 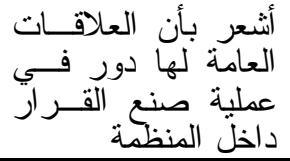 & 15 \\
\hline
\end{tabular}




\section{يتضح من نتائج الجدول السابق مايلي:}

جاءت إستجابات عينة الدراسة من المجتمع المحلي بمحافظات الدلتا

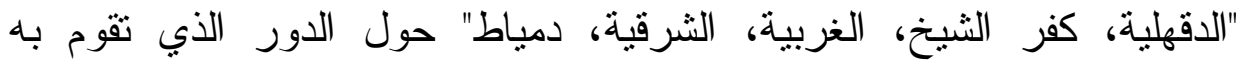

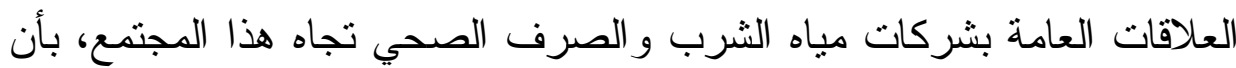

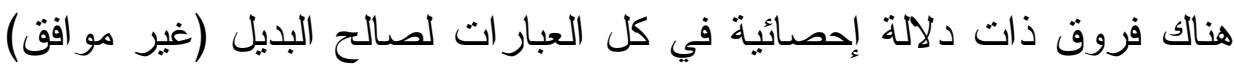

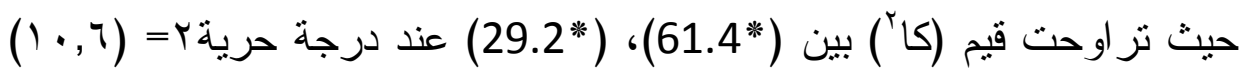
دالة عند مستوي دلالة (0., •)، وجائت العبار ات مرنبة حسب الأهمية النسبية

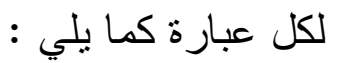
-

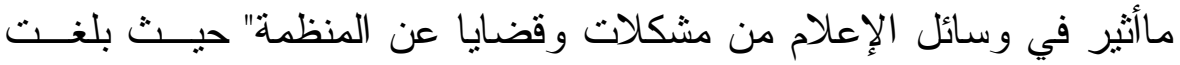

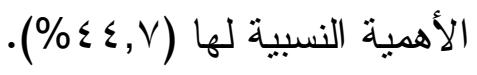

- في التزتيب الثاني العبارة رقم (1)): "يقوم جهاز العلاقات العامــة بتحقيـق

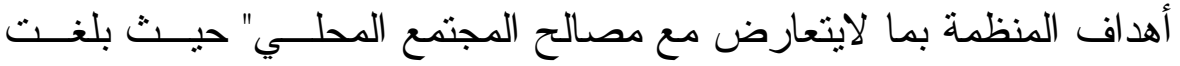

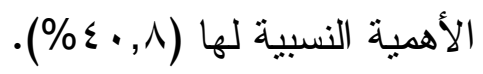

- في الترتيب الثالث العبارة رقم (ع): " يقوم جهاز العلاقــات العامــة بعدــل

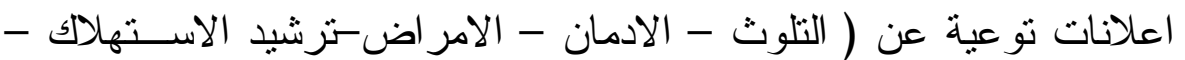

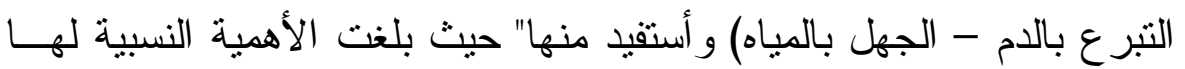
. $(\% \varepsilon \cdot, 1)$

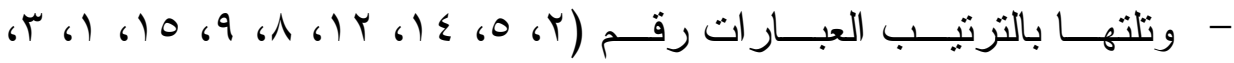

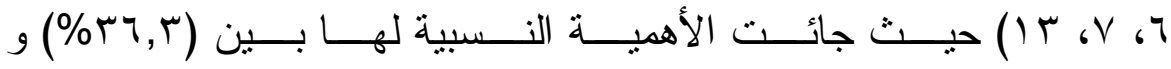
.$(\% r \varepsilon, 1)$ 
ومن خلال ماسبق قام الباحث بحساب متوسط الأهمية النسبية للعبار ات

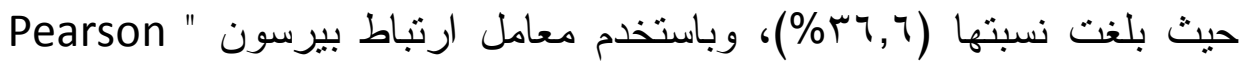
Correlation كفر الثيخ، الغربية، الثرقية، دمياط" وطبيعة دور العلاقات العامة نحو المجتمع المحلي وقضاياه في هذه المحافظات ، كما هو موضح في الجدول التالي :

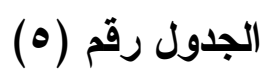

يوضح قيمة معامل إرتباط بيرسون"ر" للعلاقة بين الموقع الجغرافي لشركات المياه وطبيعة دور ممارسي العلاقات العامة بها نحو المجتمع المحلي وقضاياه

\begin{tabular}{|c|c|c|c|}
\hline المجتمع المحلي وقضاقياه العامة نحو & ل المحافظع الجغر افي & \multicolumn{2}{|c|}{ 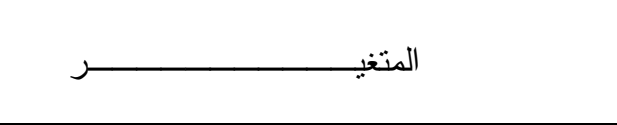 } \\
\hline 0.031 & 1 & Pearson Correlation & \multirow{3}{*}{ لمحافظات الدلتا } \\
\hline 0.572 & & Sig. (2-tailed) & \\
\hline 323 & 323 & $\mathrm{~N}$ & \\
\hline 1 & 0.031 & Pearson Correlation & \multirow{3}{*}{ دور العلاقات العامة } \\
\hline & 0.572 & Sig. (2-tailed) & \\
\hline 323 & 323 & $\mathrm{~N}$ & \\
\hline
\end{tabular}

يتضح من نتائج الجدول السابق أن العلاقــة بــين (الموقــع الجغر افـي

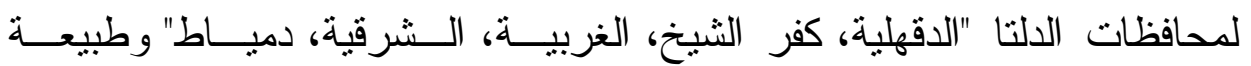

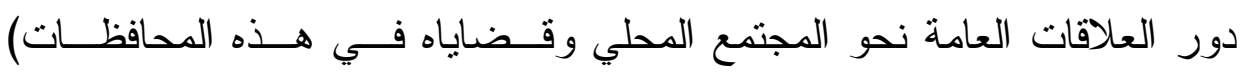
علاقة طردية (موجبة) و غير دالة إحصائيا ، حيث بلغت قيمة معامــل إرتبــاط بيرسون (ر=0.031 ) وهي قيمة موجبة غيردالة عند مستوي دلالـــة (1 ., · ) وبلغت قيمة مستوي المعنوية (OVY, · ) وتدل علي عدم وجود علاقة قوية بـين

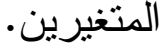


ويعزي الباحث هذه النتيجة إلــي إدر الك وفهــم مفـردات العينــة مــن

جمهور المجتمع المحلي بمحافظات الدلتا إلي طبيعة دور العلاقات العامة نحــو هذا المجتمع وقضاياه، بالإضـافة تقارب المستوي البيئي و النتـــافي و الإجتمـــاعي

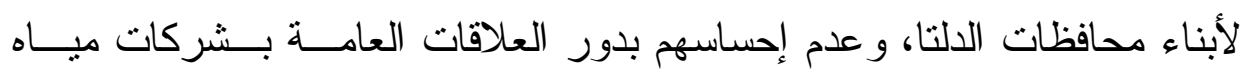

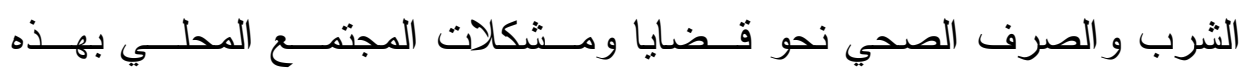
المحافظات .

ولذلك نرفض الفرض الثاني حيــث أنـــهـ لاتوجــــــــروق ذات دلالــــة

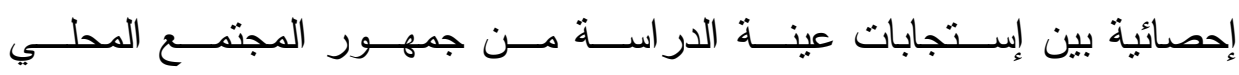
بمحافظات الدلتا "الدقهلية، كفر الثيخ، الغربية، الثرقية، دمياط" نحو الدور الذي

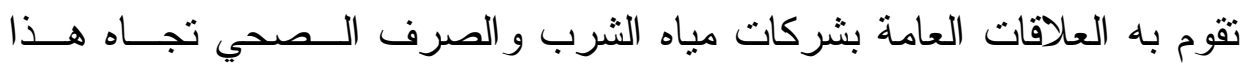

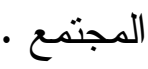

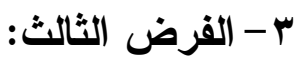

توجد علاقة إرتباطية ذات دلالة إحـصائية بــين إســتجابات ممارسـي

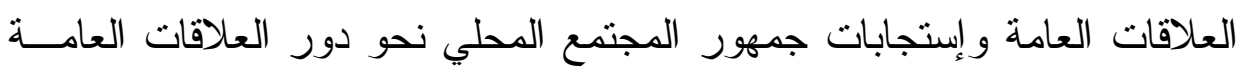
في مو اجهة قضايا المجتمع المحلي . للتحقق من صحة هذا الفرض إستعان الباحث بنتائج الجداول رقــ(Y، ؟، ع، 0) وجائت النتائج موضحة في الجدول التالي: 
جدول رقم (؟)

يوضح المتوسط المرجح لعينة الاراسة ومعامل إرتباط بيرسون (ر) حول

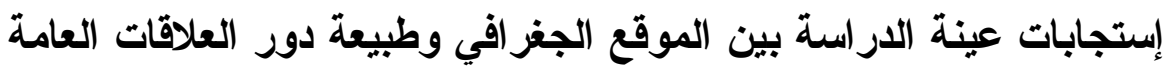

\begin{tabular}{|c|c|c|c|c|c|}
\hline \multirow{2}{*}{ معامل ارتباط } & \multicolumn{3}{|c|}{ المتوسط المرجح لإستجابات عينة الدر اسة } & \multirow{2}{*}{\multicolumn{2}{|c|}{ عدد مفردات عينة الدر اسة }} \\
\hline & غير مو افق & 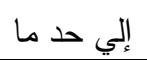 & 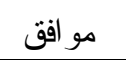 & & \\
\hline-0.008 & $14.6 \%$ & $25.6 \%$ & $59.8 \%$ & $\varepsilon$. & ممارسي العلاقات العامة \\
\hline 0.031 & $93.2 \%$ & $3.9 \%$ & $2.9 \%$ & TTM & جمهور المجتمع المحلي \\
\hline
\end{tabular}

يوضح الجدول السابق إستجابات عينة الدراسة من ممارسي العلاقات العامة بشركات مياه الثرب و الصرف الصحي بمحافظات الدلتا "الدقهلية، كفر

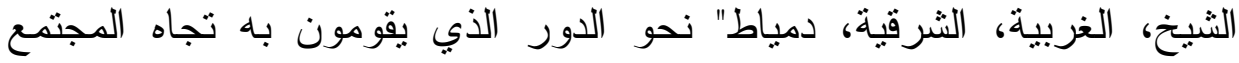

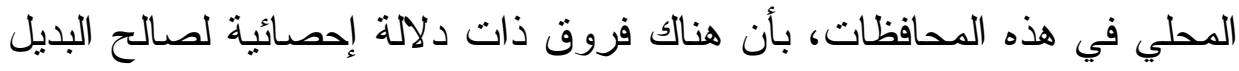
(مو افق) بنسبة (59.8\%)، وجاءت العلاقة بين (الموقع الجغر افي لثركات دات المياه وطبيعة دور ممارسي العلاقات العامة بها نحو المجتمع المحلي وقضاياه) علاقة عكسية (سالبة) وغير دالة إحصائيا، حيث بلغت قيمة معامل إرتباط بيرسون $\cdot(-0.008=ر)$

بينما جاءت إستجابات عينة الدراسة من جمهور المجتمع المحلي بهذه الدحافظات بأن هناك فروق ذات دلالة إحصائية لصالح البديل (غير موافق)

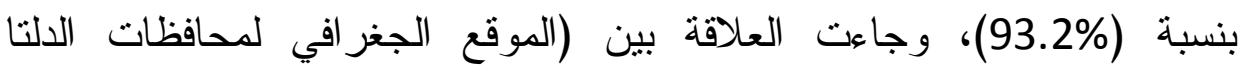
وطبيعة دور العلاقات العامة نحو المجتمع المحلي وقضاياه في هذه الدحافظات) 
علاقة طردية (موجبة) و غير دالة إحصائيا ، حيث بلغت قيمة معامل إرتباط بيرسون (ر= =0.031 ).

ويعزي الباحث هذه النتيجة إلي عدم إحساس المجتـــع المحلــي بــدور

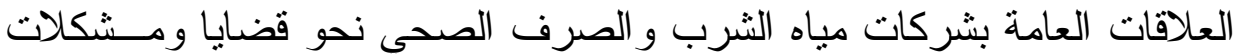
المجتمع المحلي بهذه المحافظات، فأثناء تطبيق الاستبانة تبين للباحــث إبــتياء

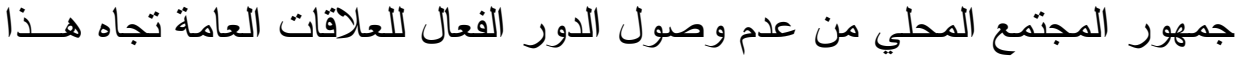

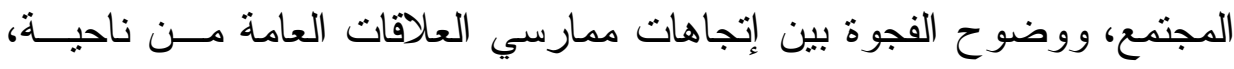

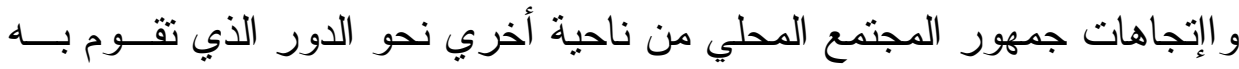
العلاقات العامة في المجتمع المحلي.

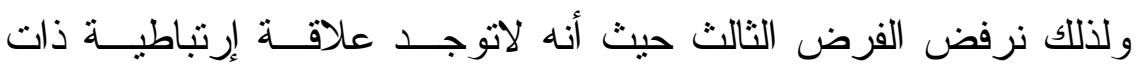

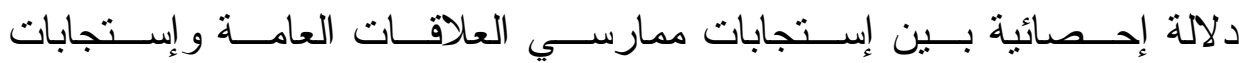
جمهور المجتمع المحلي نحو دور العلاقات العامة في مواجهة قضايا المجتـــع

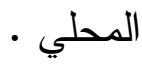

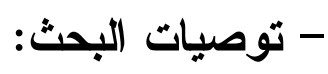
من خلال نتائج البحث يوصي الباحث بالآتي: - عمل مقررات دراسية لطلاب المدارس عن النزبية المائية،أيضا أنسشطة

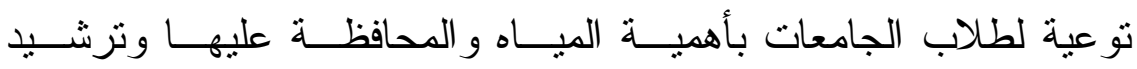
إستهلاكها. - - التسيق بين إدارات العلاقات العامة بشركات الميــاه ووســائل الإعــلام

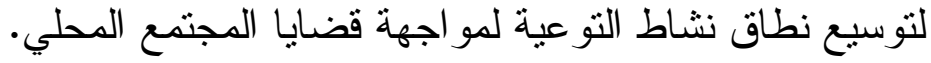


- تدريب العملي الميداني لممارسي العلاقات العامة علــي أهميـــة العمـلـ

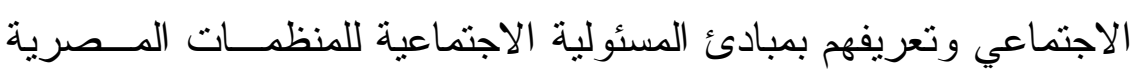

$$
\text { تجاه المجتمع المحلي. }
$$

- عمل ربط وخطوط اتصال وتو اصل بين المنظمات المــصرية للتكــاتف

$$
\text { و التكامل لمو اجهة قضايا المجتمع المحلي. }
$$

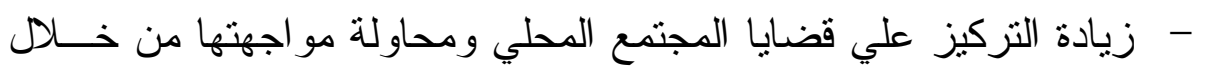
خطة توعية قوية يقوم بها ممارسي العلاقات العامة في المجتمع المحلي. - التركيز علي قضايا المجتمع المحلي لمواجهتها ووضع أنـسب الحلـــول لتلافي تأثنير ها السلبي علي المجتمع المحلي.

- عمل إرشادات علي ظهر فاتورة المياه أو مرفقة معها للتوعيــة بقـــايا

$$
\text { المجتمع المحلي ومو اجهتها. }
$$

- - ضرورة توفير الإمكانيات المادية و البشرية و التقنية اللازمــة للعلاقـات

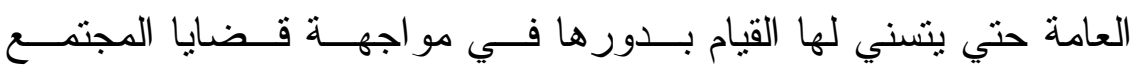

$$
\text { المحلي. }
$$




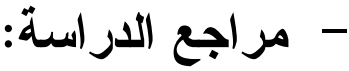

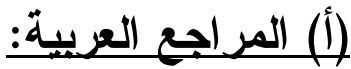

أولاً: الار اسات العربية المنشورة فى مجلات علمية: -

ا • بوزيد سليمة ، " دور ادارة السمعة الاليكترونية فى انجاح عمل العلاقات

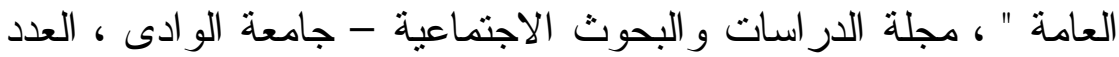

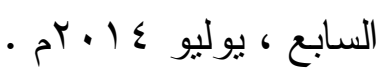

r. فاطمة عبدالكاظم الربيعي، "بر امج العلاقات العامة واســتر اتيجية بنــاء

وتعزيز سمعة المؤسسة"، مجلة الباحث العلىسى، العـد الثـد الثـامن، آزار

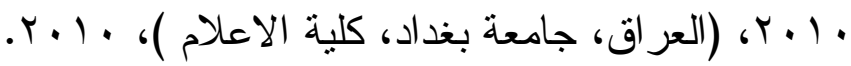

$$
\text { ثانياً: الار اسات العربية غير المنشورة: - }
$$

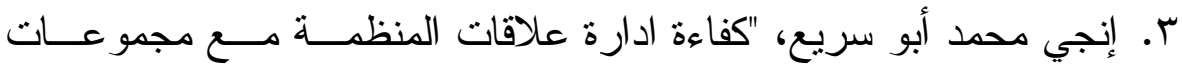
المصالح"، رسالة دكتور اه غير منشورة، (القاهرة: قسم العلاقات العامـــة

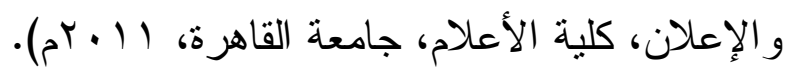

ع. إيمان محمد محمد ندا، "دور العلاقات العامــة فـــي تطبيـق المعاملـــة

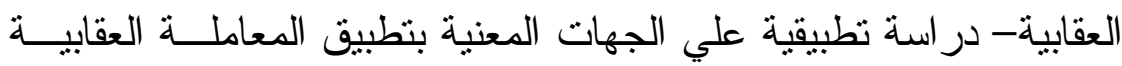
بالقاهرة الكبري"، رسالة ماجستير غير منشورة، (القاهرة: قسم العلاقات

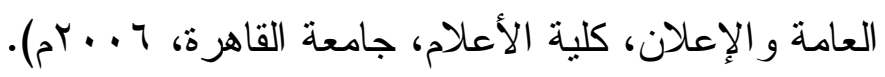

0. ر رافع در اغمة، دور دو ائر العلاقات العامة فى الجامعات الفلسطينية فـى دئ

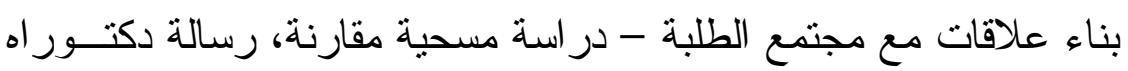
غير منشورة، ( هولندا : قسم العلاقات العامة، كلية الدراســات العاليــا،

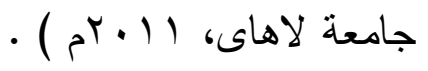

المجلد الرابع


7. ريم أحمد عادل طه، "تأثثر بيئة المنظمة على السلوك الاتصالي لجهـاز

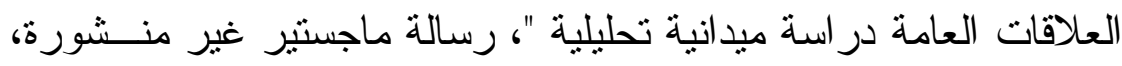
( القاهرة: قسم العلاقات العامة والإعلان، كلية الأعلام، جامعة القاهرة، .$(r \cdot r$

v. فارس نبيل عجيلات، " المسؤولية الاجتماعية في العلاقات العامــة فــي شركات الاتصالات الأردنية - دراسة حالة: شركة الاتصالات الأردنيـــة "، رسالة ماجستير غير منشورة، (الأردن، جامعة الثرق الأوسط، كليــة الآتسة

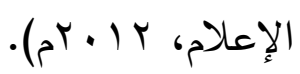

^. لبني الكنز، "دور المؤسسة الاقتصادية في تتمية المجتمع المحلي- دراسة

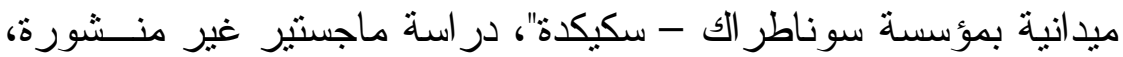

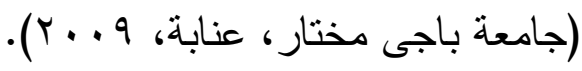

9. يعقوب يوسف علي محمد الدلي، " فاعلية الدور الإعلامي للمؤسـسات

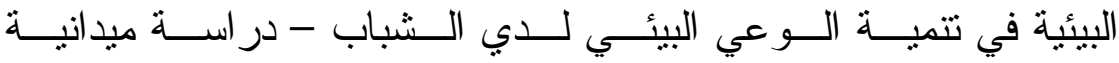

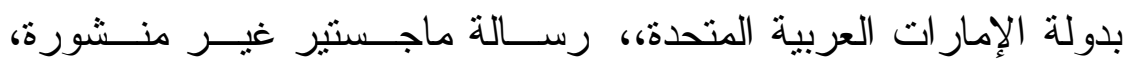

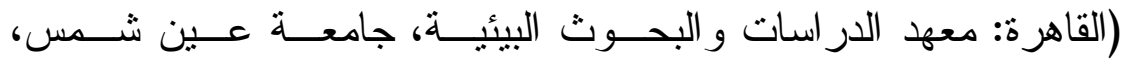

$$
\text { ثالثاً: (الكتب: }
$$

• (.حسين عبدالمطلب الاسرج، " تفعيل دور المسئولية الاجتماعية للشركات

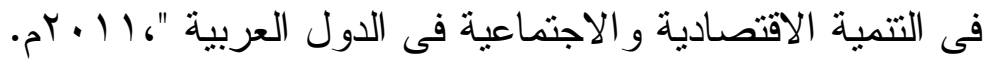

Iا.على عجوة وكريمان فريد، ادارة العلاقات العامة بين الادارة

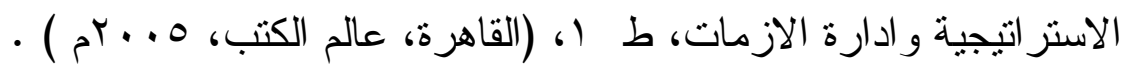


Y ا..على عجوة، العلاقات العامة بين النظرية و التطبيق، (القاهرة، عالم

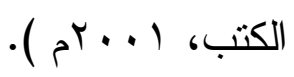

با..على عجوة، العلاقات العامة فى المنشآت المالية- المبادئ و التطبيق،

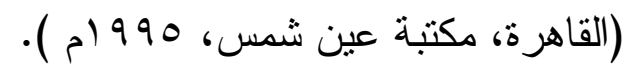

ـ ا ـ محمد جاسم فلحى، مقدمة فى العلاقات العامة و الر أى العام، (الجامعة

العربية المفتوحة فى الدنمارك، كلية الاداب و التربية، قسم الاعلام

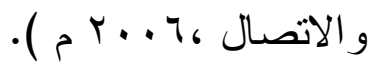

10 ا ـ محمد عبدالغنى حسن هلا، مهارات ادارة العلاقات العامة : الاتجاهات

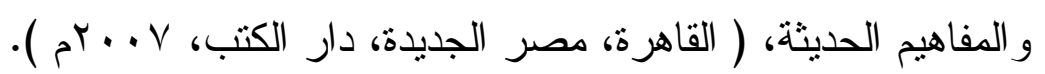

17.منال طلعت محمود ، " العلاقات العامة بين النظرية و التطبيق "،

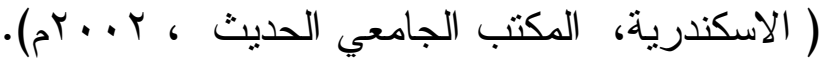

$$
\begin{aligned}
& \text { (ب) المراجع الأجنيية: }
\end{aligned}
$$

أولاً: الاراسات الاجنبية المنشورة فى مجلات علمية:

17. Cynthia E. Clark ," Differences Between Public Relations and Corporate Social Responsibility An Analysis ", Public Relations Review , 2000, Pp.

18. Holley Reeves, "Defining Public Relations' Role in Corporate Social Responsibility Programs", PR Journal, Vol. 10, No. 2 Summer/Fall 2016, (Henry W. Grady College of Journalism and Mass Communication University of Georgia), 2016.

المجلد الرابع


19. Mohammed Belal Uddin, Riad Hassan and Kazi Md. Tarique, "Three Dimensional Aspects of Corporate Social Responsibility ", ( Daffodil International University Journal of Business and Economics ), 2008.

20.P. Capriotti \& A'. Moreno, A' ngeles ," Corporate citizenship and public relations: The importance and interactivity of social responsibility issues on corporate websites ," Public Relations Review" , University Rovira Virgili, Sant Pau), 2007.

21. Zulhamri Abdullah and Yuhanis Abdul Aziz, " Managing Corporate Reputation, Stakeholder Relations, and Corporate Social Responsibility - Southeast Asian Perspective", Int.Journal of Economics and Management, ( Universiti Putra Malaysia ), 2011.

$$
\text { ثنانياً: الاراسات الاجنبية الغير منشورة: }
$$

22. Cristache, Nicoleta," The role of public relations in social responsibility of romanian enterprises , PHD, university of galati, 2006 .

23. Gourlay, "Business ethics: polarization between public relations and practice ", Lecture, (elbourne Business School, Trinity College, The University of Melbourne), 2014.

المجلد الرابع


24.Veronica Ioana Ilieş, "Public Relations and Corporate Social Responsibility: Theory and Social Action", (Babeş-Bolyai University, Cluj-Napoca, Faculty Of Sociology And Social Assistancer Doctorate In Sociology), 2011.

$$
\text { ثالثاً: الكتب الاجنبية: }
$$

25. David Crowther \& Güler Aras, Corporate Social Responsibility, 2008 .

26. Institute for Public Relations, Mini-Me History Public Relations from the Dawn of Civilization, 2006.

27. Peter Challis \& Laura Challis, The Heart of Corporate Social Responsibility, 2014.

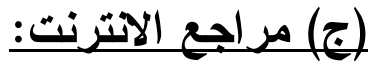
أولا: المقالات الأكاديمية باللغة العربية:

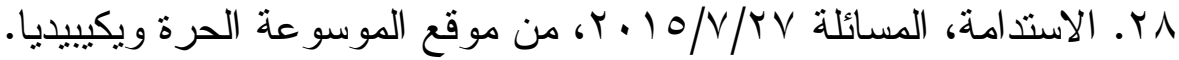
qr. د.ن، المسئولية الاجتماعية، موقع الموسوعة الحرة ويكيبيديا.

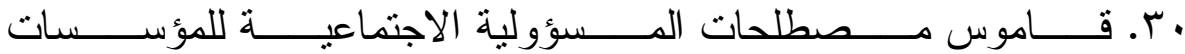
و الاستدامة، r/ 10/9 • r كموقع غرفة دبي. ثانيا : المقالات الأكاديمية باللغة الاججليزية :

31. David berlo's, David berlo's model of communication , slideshare.net, nov19, 2014, Retrieved 17-12-2016, from : http://www.slideshare.net

المجلد الرابع




\section{ملخص الدراسة باللغة العربية}

إستهدفت هذه الدراسة التعرف علي دور العلاقات العامة في مواجهة

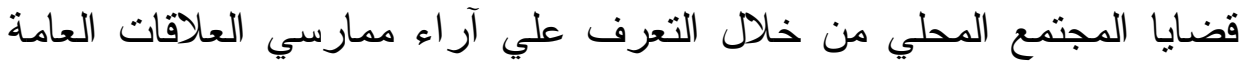
في شركات مياه الثرب و الصرف الصحي ببعض محافظات الدلتا، وأيضا جمهور المجتمع المحلي لهذه الثركات نحو الدور الذي تقدمة العلاقات العامة في مواجهة قضايا المجتمع المحلي.

و إعتمدت الدراسة علي المنهج الوصفي وعلي عينة من ممارسي العلاقات العامة قوامه ( • ع) مفردة، وعينة من جمهور المجتمع المحلي قو امها

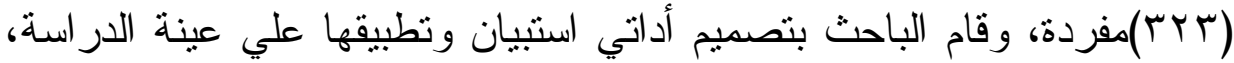
وتوصلت الدر اسة إلي:

ا - لاتوجد فروق ذات دلالة إحصائية بين إستجابات عينة الدر اسة من ممارسي

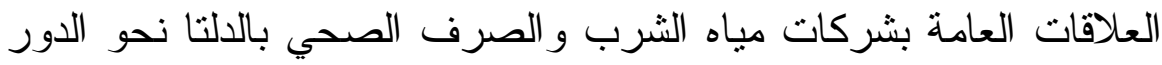
الذي يقومون بـه تجاه المجتمع المحلي. ץ- لاتوجد فروق ذات دلالة إحصائية بين إستجابات عينة الدراسة من جمهور المجتمع المحلي بالدلتا نحو دور العلاقات العامة بشركات مياه الشرب الثربه و الصرف الصحي تجاه هذا المجتمع. س- لاتوجد علاقة إرتباطية ذات دلالة إحصائية بين إستجابات ممارسي

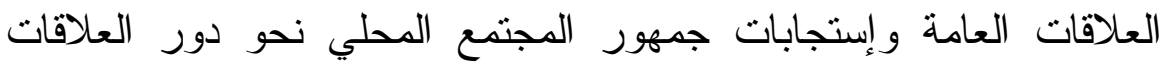

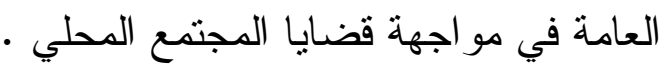
ع- إستياء جمهور المجتمع المحلي من عدم وصول الدور الفعال للعلاقات العامة تجاه هذا المجتمع، ووضوح الفجوة بين إتجاهات ممارسي العلاقات

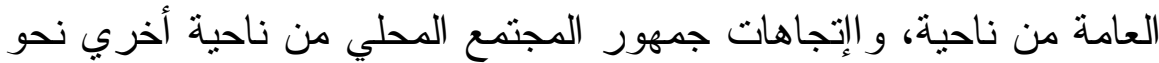
الدور الذي تقوم به العلاقات العامة في المجتمع المحلي. 


\section{ملخص الاراسة باللغة الاججليزية}

This study aimed to identify the role of public relations in facing the issues of the community by identifying the views of the public relations practitioners in the drinking water and wastewater companies in some of the governorates of Delta and the community in these companies towards the role of public relations in facing the issues of the community.

The study was based on the descriptive approach and on a sample of 40 public relations practitioners and a sample of 323 individuals. The researcher designed two survey tools and applied them to the sample of the study، and the study concluded that:

1. There are no statistically significant differences between the responses of the sample of the public relations practitioners of the water and wastewater companies in the Delta towards their role towards the community.

2. There are no statistically significant differences between the responses of the study sample from the community in the Delta towards the role of public relations in drinking water and sanitation companies towards this society. 
3. There is no statistically significant correlation between public relations practitioners' responses and community responses to the role of public relations in addressing community issues.

4. The discontent of the local public about the lack of effective public relations towards this society, and the clear gap between the attitudes of public relations practitioners on the one hand, and the attitudes of the community on the other, towards the role played by public relations in the community. 